\title{
LOS TRATADOS INTERNACIONALES EN EL ORDENAMIENTO JURÍDICO CHILENO
}

\author{
HUMBERTO NOGUEIRA ALCALÁ
}

Abogado. Doctor en Derecho, Profesor titular de Derecho Constitucional de las Universidades: Central, Diego Portales, Nacional Andrés Bello y Universidad de Valparaíso. Director del Departamento de Derecho Público de las Universidades Central y Nacional Andrés Bello

Santiago, Chile 


\section{SUMARIO}

1. CONSTITUCIÓN Y TRATADOS INTERNACIONALES. 1.1. Incorporación de los tratados al orden jurídico nacional y control de constitucionalidad. 1.2. La especial fuerza pasiva de los tratados respecto de las normas jurídicas internas. 1.3. Pérdida de eficacia y aplicabilidad de los tratados. 1.4. La relación entre tratados y leyes internas. 1.4.1. Los tratados y las leyes anteriores. 1.4.2. Los tratados y las leyes posteriores a su incorporación al derecho interno. 2. LA CONSTITUCIÓN Y LOS TRATADOS DE DERECHOS HUMANOS O DERECHOS ESENCIALES. 2.1. La concepción armónica y finalista que se desprende de la Constitución para asegurar los derechos humanos naturales. 2.2. Consecuencia de la institucionalización de derechos humanos mediante Tratados Internacionales. 2.3. Características de la constitucionalización de derechos humanos a través de tratados internacionales. 2.4. El tema de los derechos humanos es una cuestión de jurisdicción concurrente o compartida entre la interna de cada Estado y la internacional. 3. DifERENCIACIÓN ENTRE TRATADOS Y TRATADOS DE DERECHOS hUMANOS. 3.1. La diferenciación por los intereses protegidos. 3.2. La autoejecutividad de los tratados sobre derechos humanos. 3.3. La aplicación de la fuente y solución que mejor proteja los derechos. 3.4. La intangibilidad de los tratados en materia de derechos humanos. 4. MEdios INTERnaCionales de protecCión de los Derechos Fundamentales. 4.7. EI Sistema Interamericano de Protección de los Derechos Humanos. a) La Comisión Interamericana de Derechos Humanos. b) La Corte Interamericana de Derechos Humanos. 5. LA JURISPRUDENCIA CHILENA DE LOS TRIBUNALES DE JUSTICIA EN MATERIA DE LA RELACIÓN ENTRE DERECHO INTERNO Y DERECHO INternacional Bajo LA Constitución DE 1925. 5.1. La primacía del derecho internacional consuetudinario. 5.2. El período autoritario bajo la Constitución de 1980 (11 de marzo de 1980 - 11 de marzo de 1990) 5.3. La jurisprudencia de los tribunales emanada después de la reforma del artículo 5. ${ }^{\circ}$, inciso $2 .^{\circ}$, de la Constitución de 1989. a) Libertad provisional y Ley de Cheques. b) Sentencia del Juez de Castro: Imprescriptibilidad de los derechos humanos. 


\section{LOS TRATADOS INTERNACIONALES \\ EN EL ORDENAMIENTO JURÍDICO CHILENO}

POR

\section{HUMBERTO NOGUEIRA ALCALÁ}

Abogado. Doctor en Derecho, Profesor titular de Derecho Constitucional de las Universidades: Central, Diego Portales, Nacional Andrés Bello y Universidad de Valparaíso. Director del Departamento de Derecho Público de las Universidades Central y Nacional Andrés Bello

Santiago, Chile

\section{CONSTITUCIÓN Y TRATADOS INTERNACIONALES}

Es necesario determinar el sentido y alcance que tienen los tratados internacionales en el ordenamiento jurídico chileno, ya que en nuestra Constitución Política de la República no hay norma expresa que les dé una categoría determinada entre las fuentes de los derechos, por lo que ello debe determinarse por vía interpretativa.

Para ello debemos partir del hecho de que, en el ordenamiento jurídico nacional, es la Constitución Política la única habilitada para determinar la existencia de otras normas, por lo que las normas de derecho internacional tendrían validez en la medida que la Constitución lo decidiera. Pero también la Carta Fundamental, como norma fundamental, puede remitirse a normas internacionales que le son indispo- 
nibles en su propia validez, que resultarán aplicables junto con las producidas a través de los procedimientos internos previstos y regulados por la Constitución.

La soberanía no es sólo el principio fundamentador de la validez de las normas que integran un ordenamiento jurídico, sino también su condición de norma fundamentadora de la aplicabilidad de normas jurídicas que reciben su validez de normas distintas de aquellas previstas directamente por el ordenamiento soberano para la producción de nuevas normas.

"De estas dos categorías, la aplicabilidad es la única que comprende en todos sus términos la esencia del poder soberano, haciendo posible tanto la explicación de la dinámica interna de los ordenamiento estatales como la conjunción de estos últimos con las normas del denominado Derecho Internacional.»"

La aplicabilidad es la cualidad cuya consecuencia en una norma presupone como condición la validez, cuya generación transcurre por dos cauces normativos. El primero, directamente establecido por la Constitución, o el segundo, el diseñado por normas que sólo requieren de la Constitución para resultar aplicables en el ámbito regido por el ordenamiento estatal, pero no para disfrutar de validez.

Por regla general se concibe la soberanía como categoría fundamentadora de la validez de la normas, por lo que la Constitución aparece como la única norma habilitada para decidir acerca de la existencia de otras normas; por ello las normas procedentes del derecho internacional sólo disfrutarían de validez en la medida que la Constitución lo decidiera y siempre que las primeras no contradijeran los contenidos normativos de la Carta Fundamental. Esta posición, en principio correcta, no permite explicar otras vías de juridificación, ya que la Constitución, como norma superior, puede remitirse a normas que le son indisponibles en su propia validez, como son las normas internacionales, siendo el derecho internacional el que determina su creación y validez, las cuales, ya dotadas de validez, serán aplicables junto con las producidas a través de los procedimientos internos previstos y regulados por la propia Constitución.

1. Requejo Pages, Juan Luis: "Consideraciones en torno de las normas internacionales en el ordenamiento Español", Revista Española de Derecho Constitucio$n a l, n .^{\circ} 44$, enero-abril 1992, Madrid, España, págs. 43-44. 
Así, todas las normas aplicables en un ordenamiento jurídico son necesariamente válidas, pero dicha validez, que las convierte en normas aplicables, se puede originar por vía interna del Estado, a través de los procedimientos normativos diseñados por la Constitución y en los que sólo intervienen los órganos estatales, o se pueden originar por sujetos jurídicos que pueden ser independientes en su existencia de la Constitución (tratados de adhesión) o que concurren con los constitucionalmente establecidos (tratados bi o multilaterales), pero que actúan a través de procedimientos regulados por normas jurídicas internacionales independientes de las del ordenamiento jurídico constitucional, siendo dichas normas válidas, pero sólo serán aplicables en el ámbito jurídico interno de los Estados si se verifican las condiciones que haya establecido la Carta Fundamental, remitiendo a otro sistema normativo que lo acepta como propio, la determinación de validez de las normas que se incorporan al ordenamiento que organiza la Constitución.

La Constitución precisa la posibilidad y el alcance de la remisión al derecho internacional, los órganos autorizados para realizarla, los procedimientos que deben seguirse y los controles destinados a asegurar el cumplimiento de sus previsiones. La Carta Fundamental determina el proceso de integración o incorporación de la norma internacional al ordenamiento jurídico interno, lo que una vez concretado convierte a la norma internacional válida en norma internamente aplicable.

Así, tanto las normas creadas internamente como las incorporadas al ordenamiento jurídico interno de acuerdo con las normas constitucionales integran el ordenamiento jurídico.

Así, el ordenamiento jurídico nacional en su conjunto, presidido por la Constitución, "se descompone en dos subsistemas normativos, uno de los cuales depende de la Carta Fundamental para producir normas válidas (el subsistema nacional), en tanto que el otro (el subsistema internacional) sólo lo hace para dotar a sus productos normativos de la necesaria aplicabilidad, cualidad esta última que, obviamente, también reciben de la Constitución las normas internas” ${ }^{2}$.

2 Requejo Pages, Juan Luis, op. cit., pág. 47. 


\subsection{Incorporación de los tratados al orden jurídico nacional y control de constitucionalidad}

La Constitución chilena sólo se refiere a la incorporación de los tratados internacionales en los artículos $32, n .^{\circ} 17$, y $50, n .^{\circ} 1$, de la Carta Fundamental. Los tratados se entienden válidamente celebrados $\mathrm{e}$ incorporados al ordenamiento jurídico nacional cuando han sido negociados y firmados por el Presidente de la República (art. 32, n. ${ }^{\circ} 17$ ), luego aprobados por el Congreso Nacional, utilizando para ello el trámite formal de las leyes (art. 50, ${ }^{\circ}{ }^{1}$ ), luego ratificados por el Presidente de la República (art. 32, n. ${ }^{\circ} 17$ ), y publicados en el Diario Oficial, de acuerdo con las jurisprudencia sostenida de la Corte Suprema de Justicia. A su vez, el mecanismo de control que establece la Constitución para los tratados y su incorporación al orden jurídico interno, es el control preventivo de constitucionalidad que realiza el Tribunal Constitucional a requerimiento de autoridad expresamente facultada para ello (art. 82, n. ${ }^{\circ}$, de la Constitución).

Si se cumplen todas las etapas o fases del proceso de incorporación del tratado, por los órganos y los procedimientos previstos en el ordenamiento constitucional, sin que el Tribunal Constitucional, a través del control preventivo, lo haya considerado inconstitucional, estamos en presencia de un tratado válidamente celebrado e incorporado al derecho interno y sus disposiciones sólo podrán ser derogadas, modificadas o suspendidas en la forma prevista en el propio tratado o de acuerdo con las normas de la Convención de Viena sobre derecho de los tratados, de la cual Chile es Estado Parte (artículos 54 y siguientes de dicha Convención).

No deja de sorprender que nuestra Constitución no prevé la participación del Congreso Nacional junto al Ejecutivo para acordar la denuncia de un tratado, basta la sola decisión del Presidente de la República, por lo que aparece más difícil incorporar un tratado que denunciarlo. Es efectivo que al aprobar el Tratado, el Congreso aprueba las normas que determinan la posibilidad de denunciarlo, pero consideremos más conveniente que la denuncia del tratado siga el mismo procedimiento de su incorporación al derecho interno.

Puede sostenerse así que la Constitución no fundamenta la validez de la norma internacional, sino sólo su aplicabilidad. Una vez incorporada al derecho interno, la Constitución hace suya la norma internacional como las normas que de ella puedan derivarse (art. $50, \mathrm{n}^{\circ}$ 1 1), en los términos y condiciones establecidas en el tratado, por lo que 
respecto de ellas, tampoco la Constitución actúa como condición de validez.

La Constitución sólo es norma superior de las normas internacionales, en la medida que estas últimas reciben de la Carta Fundamental su condición de normas aplicables.

\subsection{La especial fuerza pasiva de los tratados respecto de las normas jurídicas internas}

Así la Constitución no es causa de la validez del tratado internacional, pero sí condición de su aplicabilidad; sin embargo, si incorporado el tratado al ordenamiento jurídico, posteriormente se modifica la Constitución, entrando la nueva disposición constitucional en conflicto con la norma del tratado, la norma internacional no pierde validez ni aplicabilidad, teniendo una especial fuerza pasiva frente a la modificación constitucional, dada por los principios de ius cogens denominados pacta sunt servanda y bona fide (cumplimiento de los tratados y buena fe, como base de la convivencia civilizada). De lo contrario, un Estado a través de una modificación a la Constitución podría alterar unilateralmente sus obligaciones e incluso sus fronteras con otros Estados.

A través de la incorporación al ordenamiento jurídico nacional de un tratado internacional, el Estado compromete su soberanía, al obligarse a aplicar y dar eficacia jurídica interna a la norma internacional incorporada, con lo que el Estado unilateralmente no podría quitarle aplicabilidad y eficacia al tratado, salvo que recurra a su denuncia o a la pérdida de vigencia de él, todo ello conforme a las reglas del derecho internacional. Ello implica, en la práctica, que un tratado incorporado válidamente al ordenamiento, siguiendo el procedimiento indicado por la Constitución a través de los órganos competentes constitucionalmente para ello, establece un ámbito de contenido normativo intangible para el legislador y el constituyente derivado, salvo que se denuncie el tratado de acuerdo con las normas del derecho internacional.

Todo ello sin perjuicio de que el contenido de los tratados referente a derechos esenciales o derechos humanos tiene rango constitucional de norma suprema, ya que constituye un límite a la soberanía del Estado, tal como lo establece el artículo $5 .^{\circ}$, inciso $2 .^{\circ}$, de la Constitución. 
Al ser la Constitución sólo condición de aplicabilidad y no de validez de la norma internacional, si ésta última se encuentra incorporada válidamente al orden jurídico interno, y ella llega a entrar en conflicto con una norma formalmente constitucional, al prevalecer sobre ésta última, lógicamente y desde la perspectiva del derecho positivo, sólo es posible concluir que la norma internacional se integra al orden constitucional a través de las normas constitucionales que posibilitan su aplicabilidad. Así, los artículos $5 .^{\circ}$, inciso $2^{\circ} ; 32, n .^{\circ} 17$, y $50 .^{\circ}, n{ }^{\circ} 1$, de la Carta Fundamental constituyen un procedimiento de incorporación de normas que actúan como fuentes formales de rango o nivel constitucional que si bien no forman parte de la Constitución formal, obligan a interpretar los preceptos jurídicos internos, inclusive los de la Constitución formal de conformidad con los tratados, instalan las disposiciones de los tratados en el nivel de Constitución material, ya que sus normas no pueden ser afectadas en su aplicabilidad por acción del constituyente derivado.

Puede sostenerse, asimismo, que un tratado celebrado con acuerdo al procedimiento previsto por la Constitución y determinado por el constituyente originario, no puede ser considerado inconstitucional si aplicamos, como estamos obligados a hacerlo, los principios de ius cogens de bona fide y pacta sunt servanda, ya que la incorporación del tratado se produce como consecuencia y actuación de la norma constitucional, la que obliga a los órganos estatales a respetar el contenido del tratado, el que amplía las normas de carácter materialmente constitucionales.

Es cierto que ello admite un procedimiento secundario de revisión o reforma de la Constitución más sencillo que los que estipula el capítulo XIV, pero no es menos cierto que los artículos $32, n .^{\circ} 17,50$, n. ${ }^{\circ} 1$, y $5 .^{\circ}$, inciso $2 .^{\circ}$, son igualmente normas constitucionales, siendo por tanto el propio constituyente, la propia Constitución, la que posibilita la utilización de este procedimiento secundario de revisión, no pudiendo olvidar, además, que el artículo $5 .^{\circ}$, inciso $2 .^{\circ}$, constituye parte de las Bases de la Institucionalidad, las cuales están dotadas de una especial fuerza normativa y preeminencia de principios y también lógica, frente al resto del ordenamiento constitucional. Ello se refuerza aún más en materia de derechos esenciales de la persona humana, ya que éstos constituyen un límite a la soberanía (art. $5^{\circ}$, inciso 20 ), es decir, al poder constituyente $y$ a los poderes instituidos.

Es tarea del propio constituyente, a través de las normas constitucionales, permitir la incorporación en condiciones más dificultosas o más fáciles de las normas internacionales al ordenamiento jurídico na- 
cional. En el derecho comparado se establece que la incorporación al derecho interno de las normas internacionales debe realizarse, si se trata de materias constitucionales, con el quórum de la reforma o revisión de la Constitución. Dicho problema es sólo de aplicación de una adecuada técnica constitucional, pero no incide sobre la validez y eficacia de las normas internacionales válidamente incorporadas al ordenamiento jurídico nacional, ya que depende del propio constituyente la regulación del procedimiento y formalidades de incorporación de los tratados al orden interno, principios y procedimientos constitucionales que no pueden ser alterados por los órganos constituidos de acuerdo con el artículo $7 .^{\circ}$ de la Constitución.

\subsection{Pérdida de eficacia y aplicabilidad de los tratados}

El Estado de Chile sólo puede excusarse del cumplimiento de un tratado internacional cuando éste se ha celebrado en forma inválida, cuando el Estado no ha concurrido a través de las autoridades constitucionalmente establecidas para comprometer la voluntad del Estado en cada etapa prevista por la Constitución, o no se ha seguido el procedimiento formal establecido por ella.

El Tratado Internacional no puede ser objeto de control represivo de constitucionalidad a través de la inaplicabilidad por inconstitucionalidad (art. 80 de la Constitución), primero por un deber de coherencia del ordenamiento constitucional frente a sus obligaciones internacionales, el Estado no puede establecer unilateralmente obstáculos al cumplimiento de sus obligaciones internacionales (art. 27 de la Convención de Viena); segundo, porque los tratados no son preceptos legales, como bien lo determina y diferencia el artículo $82, n .^{\circ} 2$, y en Derecho constitucional las diferencias de términos deben ser interpretadas siempre dándoles un sentido útil, de lo contrario, no se habrían establecido; tercero, porque el control de inaplicabilidad se refiere sólo a los aspectos de contenido de los preceptos legales, no a su procedimiento de incorporación al ordenamiento jurídico, competencia otorgada sólo al Tribunal Constitucional (art. 82, $\mathrm{n}^{\circ} 2$ ); cuarto, por cuanto el control represivo de constitucionalidad busca enjuiciar la validez del precepto legal en su aplicación al caso particular, lo que es imposible en relación al tratado, ya que no depende la validez de su contenido de la norma constitucional, ya que el órgano de control interno sólo puede pronunciarse sobre la validez de su incorporación al derecho interno, vale decir, la corrección jurídica de la actuación de los ór- 
ganos estatales que han manifestado el consentimiento internacional del Estado.

Es así que el control preventivo desarrollado por el Tribunal Constitucional tiene un carácter fundamental, por lo que es una mala técnica constitucional establecer sólo un control facultativo de constitucionalidad de las Convenciones internacionales, dicho control debería ser obligatorio, como lo son el control de los proyectos de leyes interpretativas de la Constitución y de leyes orgánicas constitucionales (art. 82, n. ${ }^{\circ} 1$ ), lo que llevaría a la prohibición de celebrar un tratado internacional que entre en conflicto con las normas sustentativas de la Carta Fundamental, salvo que se aprobara por el quórum correspondiente a la revisión de la Constitución, que nos parece la técnica constitucional correcta en tal caso.

Mientras no haya un pronunciamiento de inconstitucionalidad por el Tribunal Constitucional y no se haya obtenido la nulidad por la vía del artículo 46 de la Convención de Viena, o se haya procedido a la denuncia del tratado por la vía internacional y éste deje de serle aplicable al Estado Parte; el Estado está obligado a su cumplimiento y las normas del tratado no pueden dejar de ser aplicadas por los órganos del mismo. Si finalmente el tratado deja de ser aplicable, lo que sólo puede decidir el derecho internacional, el tratado dejará de formar parte del derecho interno, salvo que las normas del tratado sean derechos esenciales de la persona humana, los cuales una vez reconocidos y garantizados ya no pueden desconocerse, ya que constituyen límites a la soberanía estatal (art. 5, inciso $2 .^{\circ}$ ), la actuación en contrario constituye un acto nulo que origina las consiguientes responsabilidades jurídicas, como se deduce de la interpretación armónica de los artículos $5 .^{\circ}$, inciso $2 .^{\circ}, 6 .^{\circ}$ y $7 .^{\circ}$ de la Constitución. Nos parece conveniente incorporar una norma al texto de la Carta Fundamental que disponga "las normas de los tratados sólo podrán ser derogadas, modificadas, suspendidas o denunciadas, en la forma prevista en ellos o de acuerdo con los principios generales del derecho internacional.

Todo ello no es más que consecuencia del ejercicio de la soberanía de acuerdo con las normas constitucionales previstas al efecto por el poder constituyente originario, que es el que determina la idea de derecho válida que defiende la Constitución y de acuerdo con el cual deben actuar los órganos de control de constitucionalidad. No es el derecho internacional el que impone tales consecuencias jurídicas a la Constitución, sino que es la Constitución la que impone tales consecuencias respecto de las normas internacionales que son parte del ordenamiento jurídico interno. 
En todo caso, el tratado deja de ser aplicable al Estado cuando la denuncia del mismo ha sido tramitada y aceptada por las instancias competentes del derecho internacional; si ello no se obtiene, el tratado seguirá obligando al Estado. El Estado sólo se desvincula de las obligaciones del tratado cuando se cumplen tres condiciones: cuando el tratado se ha concluido de acuerdo con un procedimiento no previsto por la Constitución; que tal circunstancia haya sido formalmente determinada por el órgano de control de constitucionalidad; y que la denuncia haya sido internacionalmente aceptada de acuerdo a las normas del tratado o los principios generales del derecho internacional. La ausencia de esta última condición impide aplicar las normas del tratado, que deberá continuar aplicándose, ya que las normas internacionales que obligan a ello son parte de nuestro ordenamiento jurídico interno y, como tales, producen dicho efecto.

El respeto del Estado de Chile y de sus órganos a los tratados válidamente celebrados es condición indispensable para su mejor inserción en la comunidad internacional de naciones civilizadas y constituye una garantia para su propia seguridad como nación y su respeto como tal entre los Estados constitucionales y democráticos de Derecho.

\subsection{La relación entre tratados y leyes internas}

Para determinar el tipo de relaciones entre tratados y leyes es necesario considerar un doble criterio: por una parte, el de las consecuencias que sobre la validez de las leyes anteriores producen la incorporación de los tratados internacionales; por otra parte, el de los efectos derivados de la aplicación preferente de las normas de los tratados internacionales en relación a la aplicabilidad de las normas internas. La diversidad de criterios se debe a la distinta fuente de validez de las que reciben su existencia jurídica las leyes y los tratados, como asimismo del hecho de que ambos tipos de normas se remiten a la Constitución en lo que se refiere a su aplicabilidad, como, finalmente a la dualidad de regímenes de aplicabilidad: la ley al que dispone la Constitución, el tratado y su derecho derivado al dispuesto por el derecho internacional e incorporado al derecho interno de acuerdo con el procedimiento establecido por la Carta Fundamental. 


\subsubsection{Los tratados y las leyes anteriores}

En relación a las leyes anteriores, el tratado las modifica en las materias a las que se refiere la norma internacional; ello se deriva de la decisión de los órganos constitucionales, que, en virtud de la Constitución, determinan la sucesión de las normas internas válidas y la aplicabilidad de las normas internacionales incorporadas al ordenamiento jurídico interno. Este efecto modificador o derogador de las leyes anteriores que versan sobre la misma materia del tratado surge de los propios artículos $32, n .^{\circ} 17$, y $50, n .^{\circ} 1$, de la Carta Fundamental, en la que interviene la participación de los órganos colegisladores que determinan la aplicabilidad e incorporación al derecho interno del tratado internacional, el que desplaza a las normas internas que entran en conflicto con el tratado aprobado por los propios órganos colegisladores, los cuales expresan por tal decisión la voluntad de modificar las normas legales anteriores.

Cabe señalar que este criterio es de general aplicación por la jurisprudencia de los tribunales de justicia, el aspecto que genera una reflexión especial es en relación con las leyes que requieren de quórum especial (leyes orgánicas constitucionales y leyes de quórum calificado), en la medida que serían modificadas o derogadas por los tratados que sólo requieren de mayoría simple para su aprobación por el Congreso, como lo dispone el artículo $50, n .^{\circ} 1$, de la Constitución, lo que hace preguntarse acerca de la necesidad de que cuando un tratado verse sobre materias de ley orgánica constitucional o de ley de quórum calificado, debiera para aprobarse el tratado procederse a la utilización del quórum calificado respectivo. Frente a esta interrogante, cabe señalar que los preceptos legales tienen todos la misma eficacia y categoría de normas primarias, entre los cuales sólo opera el principio de disyunción que otorga al mismo órgano legislativo el deber de actuar con quorums diferentes ante distintas materias, reservando ciertas materias la Constitución a su desarrollo legislativo por ley orgánica constitucional y otras por ley de quórum calificado, siendo el resto de competencia del legislador ordinario, pero ello no indica niveles de jerarquía entre leyes dentro del ordenamiento jurídico interno que el constituyente no estableció. Además, es posible establecer que el artículo $50, \mathrm{n}^{\circ} 1$, de la Constitución no estableció ninguna distinción; por tanto, donde la Constitución no distingue no es válido al operador jurídico establecer distingos, con lo que es claro que la incorporación del tratado al ordenamiento jurídico interno en la forma establecida por la Constitución modifica o deroga cualquier ley anterior, sea ésta ordinaria, de quórum calificado u orgánica constitucional. 
A su vez, también puede sostenerse que la autorización constitucional de incorporación de un tratado internacional al derecho interno trae aparejada la incorporación de las normas derivadas de dicho tratado, las que producen la derogación o modificación de las normas internas vigentes al momento de la incorporación de la norma derivada.

Así la incorporación de las normas internacionales por la autorización de la Constitución produce desde el momento mismo de su vigencia interna, la inaplicación de la normas internas que contravengan las normas del tratado incorporado válidamente al ordenamiento jurídico interno.

\subsubsection{Los tratados y las leyes posteriores a su incorporación al derecho interno}

Las relaciones entre normas internacionales válidamente incorporadas al derecho interno y leyes posteriores, se rigen por el principio de la aplicabilidad, ya que ni unas ni otras se condicionan en su validez.

La consecuencia de que una norma internacional no pueda afectarse en su validez por una norma interna se deriva del principio de buena fe $\mathrm{y}$ de cumplimiento de los compromisos adquiridos que constituyen principios de ius cogens codificados por la Convención de Viena sobre derecho de los tratados a la que hemos aludido reiteradamente y que forma parte del ordenamiento jurídico chileno, constituyendo una limitación en el ordenamiento jurídico a todos los operadores jurídicos internos.

No se trata de un problema de jerarquía de los tratados sobre las leyes y sobre la Constitución, ya que el cumplimiento de los tratados no puede ser alterado por una ley o una reforma constitucional posterior; ello se debe a que las condiciones de validez del tratado vienen impuestas por el ordenamiento jurídico internacional, limitándose el ordenamiento jurídico interno a determinar las condiciones de su aplicabilidad. Una vez autorizada su aplicabilidad por el derecho interno a través del procedimiento constitucional respectivo, es nuevamente el derecho internacional el que determina la forma en que deben ser aplicadas sus normas, siendo aplicable el principio del artículo 27 de la Convención de Viena sobre Derecho de los Tratados. que determina: "Una parte no podrá invocar las disposiciones de su derecho interno como justificación del incumplimiento de un tratado", disposición que 
exige la aplicabilidad preferente de las normas internacionales sobre la normas internas.

Así, el principio pacta sunt servanda determina la aplicabilidad de los tratados que vinculan a los Estados-Partes mientras no se determine internacionalmente su inaplicabilidad. Por lo que incorporado un tratado al ordenamiento jurídico interno en forma válida, ninguna norma interna puede decidir su inaplicación ni su pérdida de validez.

No son aplicables a las normas internacionales de los tratados los principios aplicados en el derecho interno de que norma posterior deroga a la norma anterior, ni que la norma especial deroga a la norma general, ni que norma jerárquica superior derogue a la inferior, ya que tales principios sólo operan cuando la contradicción eventual producida entre dos normas puede resolverse de acuerdo al criterio de validez, por recibir las dos normas en conflicto su condición de normas válidas dadas por una norma jerárquicamente superior a ambas, lo que no ocurre con el caso de conflicto de una norma interna con una norma internacional.

Asi, no hay una prevalencia jerárquica entre leyes y tratados, por lo que ambas serán igualmente válidas aunque entren en conflicto, el tratado no determina la nulidad de la norma de derecho interno, sino que sólo prevalece la aplicabilidad de la norma internacional sobre la norma interna, porque así lo determina el derecho internacional, el que a su vez se aplica porque así lo han decidido los órganos constitucionales pertinentes en el ejercicio de la soberanía nacional (artículos $5 .^{\circ}$, inciso primero; $32, n .^{\circ} 17$, y $50, n .^{\circ} 1$, de la Constitución), pero que debe ser aplicado conforme al derecho internacional, una vez que la Constitución haya autorizado su incorporación y aplicabilidad.

De esta forma, una ley interna de quórum especial u ordinaria cede necesariamente, aunque sea posterior, frente al tratado válidamente incorporado al derecho interno, lo que no significa afectación de la validez de la ley en el ordenamiento interno.

Por tanto, cuando se desee quedar fuera de la obligación de cumplir las disposiciones de un tratado, no hay que recurrir a la vía legislativa ni a la vía constituyente interna, para cuyo objetivo son ineficaces; sólo cabe recurrir a la vía internacional del procedimiento de denuncia del tratado de acuerdo con las normas del derecho internacional.

La prevalencia del derecho interno sobre la normas del derecho internacional válidamente incorporado al derecho interno, por más que se haga efectiva (lo que no implica que se haga válida), constituye una 
violación de normas internacionales incorporadas al derecho interno, y por ello, una transgresión al derecho interno y a la Constitución, un debilitamiento del Estado de Derecho y una afectación de la seguridad nacional como del honor del Estado de Chile.

Celebrar un Tratado Internacional constituye un ejercicio de la soberanía por la autoridades que establece la Constitución, la que limita tanto la potestad constituyente como legislativa posterior, en algunos casos implica emprender un camino sin retorno, al comprometerse con normas irreversibles como son la referentes al aseguramiento de derecho esenciales o las que constituyen una comunidad económico o política, como es el caso de la Unión Europea. Lo que exige de los órganos constitucionales respectivos conciencia y seriedad en la toma de sus decisiones.

Así, ante un tratado válido e incorporado al derecho interno por el procedimiento señalado por la Carta Fundamental y una ley interna posterior válida, el conflicto debe resolverlo el juez ordinario mediante la aplicación preferente del tratado, de lo contrario, quebranta el propio ordenamiento jurídico interno y sus reglas de aplicación, además de hacer incurrir al Estado en responsabilidad internacional. Así lo entendió la Comisión de Estudios de la Nueva Constitución, en su sesión n. ${ }^{\circ} 367$, de mayo de 1978 , al reconocer la superioridad de los tratados sobre la ley, recogiendo lo que ya habían expresado los comisionados Alejandro Silva Bascuñán y Jaime Guzmán Errázuriz en la sesión del 20 de junio de 1974.

Se ha llegado a sostener por algunos autores ${ }^{3}$ que "entre la ley y el tratado no hay una relación de jerarquía, sino más bien una distribución de competencias". Al respecto cabe señalar que esta situación establecida para las leyes por la Constitución no es extensible a los tratados internacionales, ya que éstos no tienen un campo normativo acotado como los diversos tipos de leyes, éstos pueden regular cualquier materia dogmática u orgánica. El constituyente no ha delimitado su campo de acción. De esta manera, como sostiene Ignacio de Otto, "la relación entre el tratado y las leyes posteriores se basa sobre la base de reglas de aplicación". Un tratado no puede ser modificado por una ley, ciertamente, pero no significa que la ley contraria a un tratado en vigor sea nula, sino tan sólo que el tratado prevalece sobre ella. Por eso

3 Fiamma, Gustavo, y Moнor,Salvador: «La jerarquía normativa de los Tratados Internacionales", Diario El Mercurio, Cuerpo D, pág. 24 del domingo 4 de noviembre de 1994. 
"la inderogabilidad del tratado por la ley es una particular resistencia en cuanto no conlleva, como la fuerza pasiva propiamente dicha, la nulidad de la ley posterior contraria al tratado ${ }^{4}$, como se reconoce expresamente por la Comisión de Estudios de la Nueva Constitución en la sesión 371, págs. 2587 y 2588.

De esta manera, como lo señala gran parte de la doctrina comparada, posición que compartimos con otros autores nacionales, la resistencia de los tratados frente a la ley o el principio de intangibilidad de los tratados hace que éstos últimos ocupen una posición superior a la ley, construyendo un escalón supralegal ${ }^{5,6}$.

Klaus Stern nos dirá: "Cualquiera sea la teoría a la que se otorgue preferencia, en lo que hace a los efectos prácticos hay unanimidad acerca de que la regla de Derecho Internacional incorporada goza de primacía frente al Derecho Nacionalı ${ }^{7}$.

\section{LA CONSTITUCIÓN Y LOS TRATADOS DE DERECHOS HUMANOS O DERECHOS ESENCIALES}

Los Convenios o Tratados Internacionales deben ser interpretados $y$ aplicados de acuerdo con las reglas generales de cumplimiento del derecho internacional y de buena fe (bona fide, pacta sunt servan$d a)$, regla de derecho internacional que se consideran ius cogens, y además derecho consuetudinario internacional, sin perjuicio de encontrarse también estipuladas en la Convención de Viena sobre Derecho de los Tratados, el que se encuentra vigente en nuestro país, desde el 27 de enero de 1980, la cual establece en su artículo 27 que el Estado

4 DE OTto, Ignacio: Derecho Constitucional. Sistema de Fuentes, Editorial Ariel Derecho, Barcelona, España, 1987, pág. 126.

5 Ver Sánchez Rodríguez, L. I.; González Campos, I. D., y Sáenz de Santamaría, M. P.: Curso de Derecho Internacional Público, Oviedo, España, 1983, págs. 121 y ss.

6 Cosculluela Montaner, Luis: Manual de Derecho Administrativo, 3. ${ }^{\text {a }}$ edición, Editorial Civitas, pág. 132: "Los tratados tiene un valor superior a cualquier otra norma de Derecho Interno, incluida la ley... la aplicación preferente, incluso respecto de las leyes, se traduce en la previsión constitucional de que sus disposiciones no podrán ser derogadas, modificadas o suspendidas, sino en la forma prevista en los propios tratados o de acuerdo con las normas generales del Derecho Internacional".

7 STERn, Klaus: Derecho del Estado de la República Federal Alemana, Editorial Centro de Estudios Constitucionales, España, 1987, pág. 814. 
no puede invocar su propio derecho interno para eludir sus obligaciones internacionales; de hacerlo, comete un hecho ilícito que compromete la responsabilidad internacional del Estado. A su vez, el artículo 31 de la misma Convención que codifica una norma de derecho consuetudinario internacional, establece que un "Tratado debe interpretarse de buena fe conforme al sentido corriente que haya de atribuirse a los términos del Tratado en el contexto de éstos y teniendo en cuenta su objeto y fin...".

El artículo $5 .^{\circ}$ de la Constitución, que establece la limitación de la soberanía por los Derechos Humanos: "El ejercicio de la soberanía reconoce como limitación el respeto de los derechos esenciales que emanan de la naturaleza humana».

A su vez, la reforma constitucional de 1989 agregó a este inciso $2 .^{\circ}$ del artículo $5 .^{\circ}$ una oración final que introduce en el derecho interno a nivel constitucional una cláusula clara de incorporación de los tratados de Derechos Humanos a nivel constitucional, incorporando el Derecho Internacional de Derechos Humanos a la Constitución; esta oración final es la siguiente: «Es deber de los órganos del Estado respetar y promover tales derechos, garantizados por esta Constitución, así como por los Tratados Internacionales ratificados por Chile y que se encuentran vigentes".

\subsection{La concepción armónica y finalista que se desprende de la Constitución para asegurar los derechos humanos naturales}

El artículo $5 .^{\circ}$ de la Constitución de 1980, reformado en 1989, ha introducido en nuestro ordenamiento jurídico un reforzamiento en la defensa de los derechos humanos, como asimismo una alteración en la jerarquía normativa, al menos en lo que se refiere a los tratados en materia de derechos humanos.

Esta perspectiva ha generado un fuerte debate en el ámbito de la cátedra de Derecho Constitucional sobre el sentido y alcance de la reforma del artículo $5^{\circ}$, inciso $2 .^{\circ}$, de la Constitución. En las próximas páginas desarrollaremos nuestro punto de vista sobre la materia, la que compartimos con otros académicos especialistas en la materia.

Una primera afirmación que puede realizarse es que el constituyente estableció como fundamentos normativos en materia de derechos humanos los siguientes: 
a) Recoge la afirmación contenida en todas las convenciones sobre derechos humanos en el artículo primero, inciso primero, de la Constitución, de que "los hombres nacen libres e iguales en dignidad y derechos".

b) Establece en el inciso cuarto del artículo primero que "el Estado está al servicio de la persona humana y su finalidad es promover el bien común". Dicha promoción debe realizarse, tal como establece la misma disposición, "con pleno respeto a los derechos y garantías que esta Constitución establece».

c) Asume que el ejercicio de la soberanía, es decir, la potestad pública, incluido el poder constituyente derivado, tiene límites, y ellos son ulos derechos esenciales de la naturaleza humana». Esta disposición establecida por el constituyente de 1980 fue reforzada en 1989, al establecer el inciso segundo del artículo quinto, en su oración final: «Es deber de los órganos del Estado respetar y promover tales derechos, garantizados por esta constitución, así como por los tratados internacionales ratificados por Chile $y$ que se encuentran vigentes".

d) A su vez, el artículo 19, inciso primero, señala: "La Constitución asegura a todas las personas" los derechos que en tal disposición se enumeran; asimismo, el numeral 26 de dicho artículo expresa: "La seguridad de que los preceptos legales que por mandato de la Constitución regulen o contemplen las garantías que ésta establece o que las limiten en los casos en que ella lo autoriza, no podrán afectar los derechos en su esencia, ni promover condiciones, tributos o requisitos que impidan su libre ejercicio».

El constituyente, a través de estas disposiciones, en una interpretación armónica y finalista, reconoce que los derechos no los crea ni establece el Estado, sino que ellos emanan directamente de la dignidad y la naturaleza del ser humano; por tanto, el constituyente sólo se limita a reconocer tales derechos $y$ a asegurarlos, a darles protección jurídica, a garantizarlos.

Si tales derechos emanan de la naturaleza del ser humano, ellos pertenecen al hombre por el solo hecho de ser persona, y por tanto tales derechos tienen las características de ser universales, absolutos, inalienables e imprescriptibles. 
Puede sostenerse, además, que los derechos que emanan de la naturaleza humana no pueden ser enumerados taxativamente de una vez y para siempre, por cuanto los seres humanos, en el desarrollo histórico y de su conciencia, podrán ir perfeccionando los existentes y desarrollando otros nuevos. De ello se dejó expresa constancia en las Actas Oficiales de la Comisión de Estudios de la Nueva Constitución en su sesión 203, de mayo de 1961: "La protección constitucional se refiere no sólo a los derechos establecidos en ella, sino a todos los que son inherentes a la naturaleza humana", como asimismo se reconoció que tales derechos no son sólo los enumerados en el texto de la Constitución, en los capítulos segundo y tercero, "sino también los que formen parte del acervo cultural de la humanidad y que son propios de la naturaleza humana. Una afirmación similar hace el Pacto Internacional de Derechos Civiles y Políticos en su artículo $5 .^{\circ}$, pudiendo ser ampliados los derechos contenidos a otros que establezcan otros pactos posteriores.

Así la Constitución establece en el artículo $5 .^{\circ}$, inciso $2 .^{\circ}$, en forma expresa, dos modalidades de institucionalización de derechos naturaleza: la propia norma constitucional y el tratado internacional, siendo esta última la modalidad que permite incorporar a la Constitución material los derechos naturaleza que no están expresamente contenidos en el texto constitucional o no se hayan incorporado formalmente a ella a través del procedimiento de reforma de la Constitución.

La primera modalidad implica la introducción de nuevos derechos o fortalecimiento de los ya asegurados por medio del procedimiento de reforma constitucional del capítulo XIV de la Constitución.

\subsection{Consecuencia de institucionalización de derechos humanos mediante Tratados Internacionales}

Ratificado un Tratado Internacional en materia de derechos humanos, previa aprobación del Congreso, y siempre que el tratado se encuentre vigente en el ámbito internacional y nacional, ello produce las siguientes consecuencias en el ordenamiento jurídico nacional:

a) De acuerdo al artículo $5 .^{\circ}$, inciso $2 .^{\circ}$, de la Constitución, los derechos naturales asegurados en el tratado se incorporan al ordenamiento jurídico interno, formando parte de la Constitución material y adquiriendo plena vigencia, validez y eficiencia jurídicas, no pudiendo 
ningún órgano del Estado desconocerlos y debiendo, todos ellos, respetarlos y promoverlos, como asimismo protegerlos a través del conjunto de garantías constitucionales destinadas a asegurar el pleno respeto de los derechos.

Respetar los tratados establece el deber de asegurar el cumplimiento de sus disposiciones por todos los órganos y agentes del Estado, como asimismo por todas las personas que actúen dentro del ámbito jurisdiccional del Estado. Esta obligación es de carácter erga omnes o general, exigible incondicionalmente a todos los agentes y órganos del Estado.

Promover los derechos implica que el Estado, a través de sus órganos y agentes, debe adoptar todas las medidas legales, administrativas y jurisdiccionales con el fin de asegurar y garantizar el respeto de los derechos, prevenir su vulneración y eliminar los obstáculos públicos o privados que impidan el goce de los derechos.

Esta obligación no sólo se deriva del artículo $5 .^{\circ}$ de la Constitución, sino también de los mismos tratados internacionales, entre éstos del artículo $1 .^{\circ}$, común a los cuatro convenios de Ginebra de 1949, que establecen el deber de los Estados Partes de respetar y hacer respetar el Derecho Internacional Humanitario, lo que ha sido judicialmente reconocido por la Corte Internacional de Justicia de la Haya en el caso de Nicaragua-Estados Unidos, donde la Corte estableció el deber de los Estados Unidos de respetar y hacer respetar dichos convenios «en todas las circunstancias", lo que deriva no sólo de tales convenios, sino de los principios generales del derecho humanitario a los cuales los convenios dan expresión concreta ${ }^{8}$.

La Corte Interamericana de Derechos Humanos, en el caso Velásquez-Rodríguez, en sentencia del 29 de julio de $1988^{\circ}$, y del caso Godínez-Cruz, en sentencia del 20 de enero de $1989^{10}$, consideró que el artículo $1 .^{\circ}$, párrafo $1 .^{\circ}$, de la Convención Americana de Derechos Humanos, que establece para los Estados Partes la obligación de urespetar y garantizar" el libre y pleno ejercicio de los derechos asegurados en la Convención, consiste en que los Estados Partes están obligados

- Ver Cancado Trindade, Antonio Augusto: "Desarrollo de las relaciones entre el Derecho Internacional Humanitario y la Protección Internacional de los Derechos Humanos en su amplia dimensión", Revista $I I D H,{ }^{\circ}{ }^{\circ}$, San José de Costa Rica, pág. 52.

9 Sentencia caso Velásquez-Rodríguez, Serie $\mathrm{C}, \mathrm{n} .{ }^{\circ} 4$.

10 Sentencia caso Godínez-Cruz, Serie $\mathrm{C}, \mathrm{n} .{ }^{\circ} 5$. 
a "organizar todo el aparato gubernamental y, en general, todas las estructuras a través de las cuales se manifiesta el ejercicio del poder público, de tal manera que sean capaces de asegurar jurídicamente el libre y pleno ejercicio de los derechos humanos. Como consecuencia de esta obligación, los Estados deben prevenir, investigar y sancionar toda violación de los derechos reconocidos por la Convención y procurar, además, el restablecimiento, si es posible, del derecho violado y, en este caso, la reparación de los daños producidos por la violación de los derechos humanos" ". A ello agregó la Corte que la violación de derechos humanos por un simple particular, puede acarrear la responsabilidad internacional del Estado, por la "falta de la debida diligencia para prevenir la violación o para tratarla en los términos requeridos por la Convenciónn" ${ }^{12}$.

b) La vulneración de tales derechos humanos introducidos por via del tratado internacional constituye una transgresión tanto de la Constitución como del tratado internacional, con las consecuencias y responsabilidades jurídicas correspondientes.

c) El tratado en materia de derechos humanos se convierte en un procedimiento secundario de reforma constitucional establecida por el propio constituyente, al realizar la reforma constitucional de 1989, distinto del procedimiento del constituyente derivado del capítulo XIV de la Constitución.

Diversas constituciones establecen procedimientos secundarios de reforma constitucional al autorizar la cesión de facultades o atribuciones que la Constitución encomienda a órganos nacionales por medio de tratados internacionales. A manera de ejemplo, pueden señalarse las Constituciones de Luxemburgo, artículo 49; Bélgica, artículo 25 bis, y España, artículo 93. Incluso algunas Constituciones autorizan cesión de soberanía por simple ley, como ocurre con las Constituciones de Alemania, artículo 24; Italia, artículo 11, y Grecia, artículo 28.

La expresa autorización de tales cesiones o transferencias de poderes implica un procedimiento tácito y secundario de reforma constitucional. Se sustraen competencias o atribuciones a órganos nacionales, cambiando o modificándose la estructura del poder en el texto de

pág. 72.

1 Ver Serie $C, n .^{\circ} 4$, párrafo 166 , págs. $68-69$, y Serie $C, n .{ }^{\circ} 5$, párrafo 175 , y 182 , págs. 73-74. 
la Constitución, mediante un procedimiento diferente del señalado en las respectivas constituciones para su reforma.

En el fondo, hay un reconocimiento cada vez más fuerte de la crisis de la soberanía y del Estado Nacional, de la primacía del bien común internacional sobre el bien común nacional, todo lo que muestra y deja en evidencia una nueva estructuración del poder en la sociedad contemporánea. El constitucionalismo nacional, propio del Estado-Nación, cede posiciones ante un constitucionalismo supranacional e internacional, del cual forman parte los órganos judiciales supranacionales y los internacionales que protegen los derechos humanos y a escala planetaria.

d) Incorporado el derecho o su protección por medio del tratado, éste adquiere aplicación inmediata, ya que si fuera necesaria reforma constitucional para ello, no se estaría cumpliendo el deber y mandato imperativo y perentorio de respeto y promoción de los derechos establecidos a todos los órganos del Estado, ya que quedaría a voluntad o no de dicho órgano acatar el mandato constitucional.

e) Una reforma constitucional sólo podría modificar un tratado en materia de derechos humanos en la medida que implique una mayor protección y garantía de tales derechos, no pudiendo desmejorar su situación jurídica.

\subsection{Características de la constitucionalización de derechos humanos a través de Tratados Internacionales}

La institucionalización de derechos humanos mediante tratado es más efectiva y radical que el que involucran las otras vías de institucionalización de derechos humanos, ya que puede adicionar o completar los derechos ya asegurados constitucionalmente; el criterio para juzgar tales derechos no es si está el tratado de acuerdo o no con las normas constitucionales, sino que el criterio central es si el tratado que introduce el derecho produce un mejoramiento objetivo en la seguridad y garantía de los derechos en Chile, ya que tales derechos no son una creación del Estado ni del constituyente, sino que son inherentes al ser humano, correspondiendo al Estado sólo protegerlos y tutelarlos, constituyendo ellos un límite a la soberanía, a la potestad estatal, incluido el poder constituyente derivado. 
Por tanto, a través del tratado puede incorporarse una mayor protección de uno o varios derechos, en contradicción con normas constitucionales preexistentes, en cuyo caso el órgano de control de constitucionalidad deberá, de acuerdo a la concepción teleológica de la Constitución explicitada, aplicar los preceptos que brinden mayor protección a los derechos por sobre aquellos que los desconozcan o den menor protección, en virtud de la norma que los derechos humanos naturales constituyen un límite a la soberanía, siendo deber jurídico de todos los órganos estatales, incluido el Tribunal Constitucional y la Corte Suprema, respetarlos y promoverlos.

En efecto, no hay otra interpretación armónica del texto constitucional que sea coherente, además, con el tenor literal del artículo 5. ${ }^{\circ}$, sino aquella que sostiene que el constituyente originario deliberadamente subordinó la potestad estatal (soberanía) a las exigencias de la naturaleza humana, que es la que determina el derecho natural; por lo tanto, la institucionalización de tal derecho no puede constituir inconstitucionalidad, ya que el propio constituyente dejó constancia en la historia fidedigna del precepto, que el Estado debe asegurar y promover tales derechos, independientemente de si están considerados en el texto formal de la Constitución, ya que ello deriva del valor de la dignidad $y$ los derechos de la persona como valor supremo de nuestro ordenamiento jurídico (artículo $1 .^{\circ}$, en armonía con artículo $5 .^{\circ}$, inciso $2 .^{\circ}$; ambos textos constituyen bases esenciales de la institucionalidad).

Por otra parte, el tratado en materia de derechos humanos aparece mucho más vinculado al carácter de universal de los derechos humanos y permite, por esa vía, armonizar la protección de los derechos constitucionales con su actualización permanente a través de los tratados, que representan el avance de la conciencia y la cultura humana.

Ello no significa que los tratados en materia de derechos humanos quedan fuera del control de constitucionalidad, sino que el criterio de dicho control debe tener como principio rector el asegurar y mejorar la protección de los derechos humanos, lo que constituye una exigencia del bien común que es la finalidad de la actuación del Estado (artículo $1 .^{\circ}$, inciso $4 .{ }^{\circ}$ ).

Así, un tratado en materia de derechos humanos sólo puede ser declarado inconstitucional por atentar o menoscabar la esencia de los derechos (artículo $1 .^{\circ}$, artículo $5 .^{\circ}$, inciso $2 .^{\circ}$, y artículo $19, n .^{\circ} 26$ ), ya que al introducir un nuevo derecho se puede transgredir en su esencia un derecho originario o previamente incorporado; por deteriorar los derechos ya incorporados a la Constitución, o por desconocer o me- 
noscabar las garantías constitucionales de los derechos asegurados constitucionalmente.

Es así, que la voluntad del constituyente es otorgar a los tratados en materia de derechos humanos un tratamiento, jerarquía y modalidad de interpretación distinta a los otros tratados internacionales, siendo su jerarquía en el ordenamiento interno superior a la ley y al constituyente derivado, pero subordinado al constituyente originario, que estableció como base de la institucionalidad los derechos humanos y especificó que ellos limitaban la soberania o potestad del Estado.

Todo ello implica la incorporación al derecho interno, entre otros tratados y convenciones en materia de derechos humanos, del Pacto Internacional de Derechos Civiles y Políticos y el Pacto Internacional de Derechos Económicos, Sociales y Culturales de Naciones Unidas; la Convención Americana de Derechos Humanos o Convención de San José de Costa Rica, para sólo señalar los más importantes.

Los derechos contenidos en los tratados en materia de derechos humanos forman parte de la Constitución material, constituyendo parte del plexo de derechos garantizados constitucionalmente y constituyen límites a la soberanía, es decir, al ejercicio del poder constituyente derivado y los poderes constituidos que ejercen las potestades públicas, así éstos pueden sólo asegurar, garantizar y promover en mejor forma los derechos esenciales de la persona humana, pero jamás podrán afectar la esencia de los derechos ni disminuir su nivel de actual garantía constitucional; sólo podrán incrementarla hacia el futuro, lo que vale también para el constituyente derivado o instituido. Así lo determina el artículo $5 .^{\circ}$, inciso $2 .^{\circ}$, de la Constitución, en su oración final, por decisión del cuerpo político de la sociedad, actuando en ejercicio de la soberanía y como constituyente originario en el plebiscito de julio de 1989.

El criterio para juzgar la compatibilidad con la Constitución de los derechos institucionalizados por vía de tratado internacional es el criterio de si con ello se refuerza o se mejora objetivamente la seguridad y garantía de los derechos esenciales, los cuales, siendo tales, constituyen un límite al poder constituyente y legislativo; por tanto, el Tribunal Constitucional, de acuerdo al artículo $82, n .^{\circ} 2$, sólo podrá declarar si sus normas desmejoran la situación de los derechos esenciales ya asegurados o afectan negativamente el nivel de garantías que ellos ya tienen en nuestro ordenamiento jurídico.

En tal posición se encuentra una parte mayoritaria de la doctrina nacional, entre quienes puede señalarse a Alejandro Silva Bascuñán, 
Francisco Cumplido, Santiago Benadava, Cecilia Medina, Rodrigo Díaz Albónico, Paulino Varas, Salvador Mohor, José Luis Cea, Natacha Panatt, Claudio Troncoso, Mario Calderón, Enrique Evans de la Cuadra, entre otros ${ }^{13}$.

Un sistema de derecho en un Estado constitucional debe interpretarse de modo que logre su total plenitud a través de dos fuentes de retroalimentación: la interna de cada Estado y la internacional, lo que es aplicable en la materia que nos interesa tanto a la Constitución de 1925 como a la Carta Fundamental de 1980.

\subsection{El tema de los derechos humanos es una cuestión de jurisdicción concurrente o compartida entre la interna de cada Estado y la internacional}

Ello obliga al Estado a resolver las materias de derechos humanos de conformidad con el sistema internacional (universal o regional)

13 Silva Bascuñán, Alejandro: "Reformas sobre Derechos Humanos", Revista Chilena de Derecho, volumen 16, Universidad Católica de Chile, septiembre-diciembre 1989. Medina, Cecilia: Constitución, Tratados y Derechos Esenciales, Editorial Corporación de Reparación y Reconciliación, Santiago, Chile, 1994. Diaz AlbónICO, Rodrigo: La Reforma del artículo $5 .^{\circ}$ de la Constitución Política, Instituto de Estudios Internacionales, Universidad de Chile, 1991. Cumplido, Francisco, y NoguelRA, Humberto: Teoría de la Constitución, 3. edición, Universidad Nacional Andrés Bello, Santiago, 1994. Benadava, Santiago: Derecho Internacional Público, 4. Edición. Editorial Jurídica Conosur. Santiago, 1993, página 104, nota n. ${ }^{\circ} 6$. MoHOR, Salvador: Elementos de Juicio para la interpretación del artículo $5 .^{\circ}$, inciso $2 .^{\circ}$, Facultad de Derecho, Universidad Central, 1991, págs. 227 y ss. Posición contradictoria con su artículo en colaboración con Gustavo FIAMMA, del Diario El Mercurio del 4 de noviembre de 1994, cuerpo D, págs. 24 y 25. VARAS Alfonso, Paulino: "El respeto a todo derecho inherente a la persona, aunque no esté contemplado en el texto de la Constitución", XXIV Jornadas de Derecho Público, Revista Chilena de Derecho, Facultad de Derecho, Universidad Católica de Chile, volumen $20, n .^{\circ} 2$ y 3 , tomo II, mayo a diciembre 1993, págs. 725 y 729 . Troncoso, Claudio, y Vial, Tomás: "Sobre los derechos humanos reconocidos en tratados internacionales y en la Constitución", XXIV Jornadas de Derecho Público, Revista Chilena de Derecho, Universidad Católica de Chile, volumen 20, n. $^{\circ} 2$ y 3 , tomo II, mayo a diciembre 1993, págs. 695-704. PanatT, Natacha: "La modificación del artículo $5 .^{\circ}$ de la Constitución Chilena de 1980, en relación con los Tratados", XX Jornadas Chilenas de Derecho Público, Universidad de Valparaíso, Editorial Edeval, Valparaíso, Chile, 1990, págs. 585-603. CALDERÓN VARGAS, Mario: "Las inmunidades de jurisdicción y los derechos de la persona humana", en colección de Estudios Jurídicos en Homenaje al Profesor Alejandro Silva Bascuñán, Ed. Facultad de Derecho, Pontificia Universidad Católica de Chile, Santiago, Chile, 1994, págs. 271 y 281. Evans de LA CuAdra, Enrique: "¿Hermetismo Constitucional?", Diario La Época, domingo 20 de noviembre de 1993. 
del que el Estado es parte, lo que impone el deber, a éste último, de que tales derechos se hagan efectivos en su jurisdicción interna, como lo exige también nuestro artículo $5 .^{\circ}$, inciso $22^{\circ}$, de la Constitución. Así, es en el ámbito del Estado donde los derechos deben lograr efectividad, pero es el derecho humanitario internacional y el derecho internacional de los derechos humanos el que determina las directrices dentro de las cuales el derecho interno tiene que resolver la materia concreta referida de derechos de la persona humana, en lo que se refiere a las personas que se encuentren sometidas a su jurisdicción.

Desde la vigencia de la Carta de Naciones Unidas, nos dice Verdross, se ha "roto con el principio de que un Estado puede tratar a sus súbditos a su arbitrio, sustituyéndolo por el principio nuevo de que la protección de los derechos humanos constituye una cuestión fundamentalmente internacional ${ }^{14}$. Nuestro país es signatario de la Carta de Naciones Unidas y se encuentra vinculado por sus decisiones y por la Declaración Universal de Derechos Humanos y sus pactos complementarios.

Cualquiera que sea la posición que se tenga sobre la vinculación de la Declaración Universal de Derechos Humanos de 1948, es un hecho no discutible que la Declaración de Teherán de 1968 la hizo obligatoria para la comunidad internacional. A su vez, la Declaración Americana de Derechos y Deberes del Hombre de 1948 es claramente obligatoria y vinculante también por la remisión que a ella efectúa el artículo 29, inciso d), de la Convención Americana sobre Derechos Humanos o Pacto de San José de Costa Rica. Ambas declaraciones son fuentes de derechos materialmente constitucionales.

\section{DIFERENCIACIÓN ENTRE TRATADOS Y TRATADOS DE DERECHOS HUMANOS}

\subsection{La diferenciación por los intereses protegidos}

En materia de tratados sobre derechos humanos, éstos tienen características especiales que los diferencian de todo otro tipo de tratados, como to ha señalado la Corte Internacional de Justicia; en ellos

14 Verdoross: Derecho Internacional Público, Madrid, España, 1967, pág. 492. 
"los Estados contratantes no tienen intereses propios, tienen solamente, todos y cada uno de ellos, un interés común, que es el de preservar los fines superiores que son la razón de ser de la Convención". "En consecuencia, en una Convención de este tipo no puede hablarse de ventajas o desventajas individuales de los Estados, ni de mantener un equilibrio contractual exacto entre derechos y deberes. La consideración de los fines superiores de la Convención es, en virtud de la voluntad de las partes, el fundamento y medida de todas las disposiciones» (opinión consultiva CID Recueil 1955, página 23). Esta concepción de los tratados en materia de derechos humanos es sostenida también por la Corte Interamericana de Derechos Humanos, al establecer que estos instrumentos "no son tratados multilaterales de tipo tradicional concluido en función de un intercambio recíproco de derechos, sino el beneficio mutuo de los Estados contratantes. Su objeto y fin son la protección de los derechos fundamentales de los seres humanos independientes de su nacionalidad, tanto frente a su propio Estado como frente a los otros Estados contratantes. Al aprobar estos tratados sobre derechos humanos, los Estados se someten a un orden legal dentro del cual ellos, por el bien común, asumen varias obligaciones, no en relación con los Estados, sino hacia los individuos bajo su jurisdicción" (opinión consultiva $O C-82$, Serie $A, n .{ }^{\circ} 2$, párrafo 29 ), fundamentos que hacemos nuestros.

A su vez, es necesario precisar, desde la perspectiva del derecho convencional internacional establecido en la Convención de Viena sobre Derecho de los Tratados de 1969, el que se encuentra ratificado por Chile y vigente, establece en el artículo 60 que se excluye todo tipo de reciprocidad para las disposiciones relativas a protección de las personas en los tratados humanitarios, lo que se aplica también a las Convenciones de Derechos Humanos.

La Corte Permanente de Justicia Internacional ha resuelto que "es un principio de Derechos de Gentes generalmente reconocido que en las relaciones entre potencias contratantes las disposiciones del derecho interno no pueden prevalecer sobre los de un Tratado" (Serie $\mathrm{B}, \mathrm{n} .^{\circ} 17$, página 32 ) y que "un Estado no puede invocar frente a otro Estado su propia Constitución para sustraerse a las obligaciones que impone el Derecho Internacional a los Tratados vigentes" (Serie A/B, $n .^{\circ} 44$, página 24). Criterios interpretativos que compartimos ampliamente.

En materia de derechos humanos, el juez debe interpretar los tratados teniendo en cuenta su fin último, que es la protección de los derechos de la persona humana, valor y principio fundamental y clave 
esencial para la interpretación de todo nuestro ordenamiento constitucional, como también lo establece la Constitución Política de la República en sus artículos $1 .^{\circ}, 5 .^{\circ}$, inciso $2 .^{\circ}$, y $19, n . .^{\circ} 26$, en una interpretación sistemática y finalista.

La interpretación de los derechos en la jurisdicción interna no admite desvinculación de la interpretación hecha por la jurisdicción internacional respecto de los derechos asegurados por los convenios o tratados internacionales incorporados al ordenamiento jurídico chileno.

La Corte Interamericana de Derechos Humanos, en su opinión consultiva OC-1/82, del 24 de septiembre de 1982, ha establecido la integración y la complementariedad de los sistemas regionales $y$ universales de protección de los derechos humanos; al respecto señaló:

"En la Convención se advierte una tendencia a integrar el sistema regional y el sistema universal de protección de los derechos humanos. En el Preámbulo se reconoce que los principios que sirven de base a los Tratados han sido consagrados en la Declaración Universal de Derechos Humanos y han sido reafirmados y desarrollados en otros instrumentos internacionales tanto de ámbito universal como regional» (párrafo 41), agregando que "el propósito de integración del sistema regional con el universal se advierte igualmente en la práctica de la Comisión Interamericana de Derechos Humanos, perfectamente ajustada al objeto y fin, la Convención de la Declaración Americana y del Estatuto de la Comisión" (párrafo 43); la doctrina ha afirmado en forma unánime la misma posición ${ }^{15}$.

En la Convención Americana sobre Derechos Humanos, democracia y derechos humanos están vinculados intrínsecamente, en el

15 Monroy Cabra, Marco Gerardo: Los Derechos Humanos, Ed. Themis, Bogotá, Colombia, 1980, pág. 109. NiKKEN, Pedro: La Protección Internacional de los Derechos Humanos, su desarrollo progresivo, Ed. Instituto Interamericano de Derechos Humanos, Editorial Civitas, Madrid, España, 1987, págs. 47-58. NieTo NAviA, Rafael: Introducción al Sistema Interamericano de Protección de los Derechos Humanos, Editorial IIDH-Universidad Yoveriana, Bogotá, Colombia, 1988, pág. 67. DunsheE de Abranches, Carlos: "Estudio Comparativo entre los Pactos de las Naciones Unidas sobre Derechos Civiles, Políticos, Económicos, Sociales y Culturales y los Proyectos de la Convención Americana sobre Derechos Humanos", Anuario Interamericano de Derechos Humanos, Washington, EE.UU., 1968, pág. 6. Gross EsPIELL, Héctor: La Constitución Americana y la Convención Europea de Derechos Humanos. Análisis Comparativo, Editorial Juridica de Chile, Santiago de Chile, 1991, pág. 19. 
preámbulo, cuando se sostiene que «el respeto de los derechos esenciales del hombres se ha de realizar «dentro del cuadro de instituciones democráticas». A su vez, el artículo 29 de la Convención Americana prohíbe toda interpretación de la Convención que excluya otros derechos y garantías que son inherentes al ser humano o que se derivan de la forma democrática representativa de gobierno.

Ello se ve reforzado por la jurisprudencia de la Corte Interamericana, a través de las opiniones consultivas 2, del 24 de septiembre de 1982, párrafo 31; 5, del 13 de noviembre de 1985, párrafos 41 y 44; 8 , del 30 de enero de 1987, párrafo 26, y 9, del 6 de octubre de 1987, párrafo 35 .

Así, en la OC5/85 se señala que «las justas exigencias de la democracia deben, por consiguiente, orientar la interpretación de la Convención $y$, en particular, de aquellas disposiciones que están críticamente relacionadas con la preservación y el funcionamiento de las instituciones democráticas (párrafo 44).

Así, el contenido del literal b) del artículo 29 de la Convención Americana de Derechos Humanos ha establecido como regla hermenéutica que ninguna disposición de un tratado puede ser interpretada en el sentido de "limitar el goce y ejercicio de cualquier derecho o libertad que puede estar reconocido de acuerdo con las leyes de cualquiera de los Estados partes, o de acuerdo con otra convención en que sea parte uno de dichos Estados". Una regla prácticamente idéntica está establecida en el Pacto Internacional de Derechos Civiles y Políticos. Tal regla Ilevó a la Corte Interamericana de Derechos Humanos a sostener en su opinión consultiva $1 / 82$ que su competencia consultiva puede ejercerse respecto de toda disposición concerniente a la protección de los derechos humanos de cualquier tratado internacional aplicable en los Estados americanos, con independencia de que sea bilateral o multilateral, de cuál sea su objeto principal o de que sean partes o puedan ser partes del mismo tratado Estados ajenos al sistema interamericano.

Hay asi toda una estructura de principios y valores que, coordinados con el objeto y fin de los tratados de derecho humanitario (Convenciones de Ginebra de 1949 y protocolos complementarios) y los principios y tratados de derecho internacional de los derechos humanos (Declaración Universal de Derechos Humanos, Declaración Americana de Derechos Humanos y Convenciones posteriores complementarias), deben cumplirse de buena fe. Ello implica que los silencios, los implícitos, y el amplio arsenal axiológico que los nutre, tiene un senti- 
do de vigor aplicativo, directo e inmediato en el ordenamiento jurídico, atribuyéndole toda su fuerza y valor normativo ${ }^{16}$.

Dejar de cumplir con las normas internacionales en materia de derechos humanos implica un desconocimiento de esos derechos, que los Tribunales, como órganos del Estado, deben respetar y promover.

Los tribunales de justicia no estarían dando cumplimiento al deber establecido en las Bases de la Institucionalidad, artículo $5 .^{\circ}$, inciso $2 .^{\circ}$, si por acción o por omisión no aplican la normativa relativa a los derechos humanos reconocidos en el ordenamiento constitucional o en los tratados incorporados válidamente al ordenamiento jurídico, principio hermenéutico que no sólo es válido para la Constitución de 1980, sino que también rige durante la vigencia de la Carta de 1925.

\subsection{La autoejecutividad de los tratados sobre derechos humanos}

El carácter de autoejecutividad de las normas de un tratado consiste en la posibilidad de aplicar sus disposiciones directamente en el derecho interno, sin necesidad de obtener un desarrollo legislativo previo, lo que equivale en derecho constitucional a los preceptos o normas operativas de la Constitución, es decir, las normas que debe considerar en forma directa y en primer lugar el juez o la administración para resolver cualquier asunto sometido a su consideración.

La norma autoejecutable se caracteriza por establecer un derecho en favor de la persona que tiene un interés legítimo en la aplicación del precepto cuya protección es exigible al juez en sus resoluciones judiciales o a la administración en sus actuaciones administrativas.

Como lo sostuvo la Corte Permanente de Justicia Internacional, en el caso Foster y Neilson, estamos en presencia de normas autoejecutables por sí mismas en un tratado, cuando la intención de las partes ha sido garantizar un derecho exigible a las personas que soliciten a los organismos del Estado la aplicación de esa norma en su favor.

16 Garcia de Enterria, Eduardo: La Constitución como norma y el Tribunal Constitucional, Madrid, España, 1991. 
En el caso de la Convención Americana de Derechos Humanos o Pacto de San José de Costa Rica, el propio preámbulo explicita como fines de ese tratado el establecer un régimen de "protección internacional, de naturaleza coadyuvante o complementaria de la que ofrece el derecho interno de los Estados Americanos»; ello se refuerza con el artículo 1 de la Convención, que señala: "Obligación de respetar los derechos. 1: los Estados Partes de esta Convención se comprometen a respetar los derechos y libertades reconocidos en ella $y$ a garantizar su libre y pleno ejercicio a toda persona que esté sujeta a su jurisdicción, sin discriminación alguna por motivos de raza, color, sexo, idioma, religión, opiniones políticas o de cualquier otra índole, origen nacional o social, posición económica, nacimiento o cualquier otra condición social. 2: Para los efectos de esta convención, persona es todo ser humano".

Así todos los preceptos de la Convención Americana de Derechos Humanos son de autoejecutividad directa, a menos que exista una estipulación expresa en la norma que condiciona el cumplimiento de la norma al desarrollo de leyes subsecuentes.

Por tanto, el artículo $2 .^{\circ}$ de la Convención Americana, que establece la obligación de adoptar, con arreglo a sus procedimientos constitucionales y a las disposiciones de la Convención, las medidas legislativas o de otro carácter que fueren necesarias para hacer efectivos los derechos de la Convención, constituye una obligación complementaria, lo que no releva al Estado de la obligación de respeto y de garantía de los derechos que establece el artículo $1 .^{\circ}$ de la Convención.

La autoejecutividad de la Convención Americana de Derechos Humanos ha sido ratificada por la Corte Interamericana de Derechos Humanos en su Opinión Consultiva OC-7, del 29 de agosto de 1986, sobre el derecho de rectificación o respuesta, en relación con los artículos 1.1 y 1.2 de la Convención, a solicitud del gobierno de Costa Rica; en ella la Corte rechazó el argumento de la no autoejecutibilidad del artículo 14.1, en virtud de que «el sistema mismo de la Convención está dirigido a reconocer derechos y libertades a las personas y no a facultar a los Estados para hacerlo», por lo que concluye que el derecho de rectificación o respuesta es internacionalmente exigible.

Jiménez de Arechaga ha establecido que, con el criterio antes señalado, confirmado por la Corte Interamericana de Derechos Humanos, "solamente carecen de autoejecutividad los artículos 13 (4), sobre propaganda en favor de la guerra y apología del odio; 17 (4), sobre igualdad de los hijos, sean legítimos o naturales; 19, sobre derechos del ni- 
ño a medida de protección; 21 (3), sobre prohibición de la usura, y 26, sobre derechos económicos, sociales y culturales" ${ }^{17}$.

Sobre la autoejecutividad de los derechos garantizados por la Convención Americana también hay jurisprudencia de Cortes Supremas de la región. Sólo a modo ejemplar puede citarse el caso de la Corte Suprema de Venezuela ${ }^{18}$, que toca a la autoejecutividad del artículo 25 de la Convención Americana, que garantiza la acción de amparo constitucional de todos los derechos, y la operatividad del artículo 49 de la Constitución de Venezuela, que armoniza con ella, señalando:

"La norma transcrita ha sido objeto de divergente interpretación por tanto por parte de la doctrina como de la jurisprudencia nacionales, pues mientras algunos consideran que se trata de una norma simplemente programática cuya aplicación queda diferida hasta que se dicte la ley especial que regule la materia, otros estiman que la ausencia de este instrumento legal no impide el ejercicio del recurso de amparo, y en apoyo de este último criterio se invoca especialmente el aparte del artículo 50 de la propia Constitución, que establece:

“La falta de ley reglamentaria de estos derechos no menoscaba el ejercicio de los mismos." "

"Considera la Corte que con esta declaración el constituyente ha reafirmado su voluntad en el sentido de mantener la integridad de los derechos humanos y de ponerlos a cubierto de cualquier intento $o$ acto que pudiese vulnerarlos, ya que, en su concepto, la diferencia que ha pretendido hacerse entre derechos y garantías es inadmisible, desde el momento que haría de aquéllos meras declaraciones retóricas sin contenido real.»

"Al admitir la posibilidad del ejercicio actual del recurso de amparo, no puede la Corte dejar de advertir que los tribunales de la República deben hacer uso prudente y racional de la norma contenida en el artículo $4 .^{\circ}$ de la Constitución, tratando de suplir por medio de la analogía y demás instrumentos de interpretación de los que provee el sistema jurídico venezolano, la lamentable ausencia de una ley reglamentaria de la materia."

17 Jiménez de ARECHAGA, Eduardo: "La Convención Interamericana de Derechos Humanos como Derecho Interno", en Revista IIDH, enero-junio de 1988, San José de Costa Rica, pág. 35.

is Sala Politica Administrativa, caso Andrés Velásquez contra Consejo Supremo Electoral. Citado por Carlos AYALA CoRAO, "El Derecho de los derechos humanos", en Lecturas Constitucionales Andinas, n. ${ }^{\circ} 3$, Comisión Andina de Juristas, Limá, Perú, 1994, pág. 61. 
En un sentido similar, la Corte Suprema Argentina creó el Amparo de derechos fundamentales por vía jurisprudencial en los casos de Siri y Kot.

Concordamos con nuestro colega y amigo Germán Bidart Campos en que el principio es el de presunción de operatividad de las cláusulas del Pacto, y sólo cuando de la redacción de la norma surge en forma clara que es programática, ella lo será ${ }^{19}$. Sin embargo, si la cláusula es programática, obliga al legislador a hacer lo que ella determina; si no lo hace, fuera de incumplir una obligación internacional emanada de un Tratado, estaría incurriendo en una especie de inconstitucionalidad por omisión.

Que el artículo $2 .^{\circ}$ de la Convención Americana de Derechos Humanos establece la obligación inmediata de los Estados Partes de adoptar las medidas legislativas "o de otro carácter" que sean necesarias para hacer efectivos los derechos (compete a los tribunales de justicia, a través de sus sentencias, hacer efectivas esas medidas), lo que permite la aplicación ágil y eficaz de todo el sistema de derechos que forman parte del ordenamiento jurídico nacional, con su doble fuente de derechos, los reconocidos por vía normativa interna y los reconocidos e incorporados al orden jurídico nacional provenientes de la vía normativa internacional (principio de ius cogens, derecho consuetudinario y derecho convencional internacional), dando plenitud al sistema de protección de derechos humanos en el sistema constitucional, permitiendo la retroalimentación y armonización de ambas fuentes de derechos ${ }^{20}$.

\subsection{La aplicación de la fuente y solución que mejor proteja los derechos}

Un tribunal de justicia en un Estado Constitucional de Derecho, como lo era el vigente bajo la Carta de 1925 como el actual bajo el imperio de la Constitución de 1980, debe aplicar la regla hermenéutica que permite emplear correctamente la opción preferencial por la fuen-

19 BidaRT CAmpos, Germán: La interpretación del sistema de derechos humanos, Editorial Ediar, Buenos Aires, Argentina, 1994, pág. 185.

20 Piza, Rodolfo, y Trejos, Gerardo: Derecho Internacional de los Derechos Humanos, San José, Costa Rica, 1989, págs. 117, 110 y 125. 
te y la solución que mejor favorezca la dignidad y los derechos de la persona humana, ya que, como lo sostenían viejos axiomas romanistas, todo el derecho está constituido por causa del hombre, $y$ podemos agregar, para su dignificación, lo que implica el respeto, garantía y promoción de los derechos humanos, provenientes tanto de fuente interna como de la fuente internacional válidamente incorporada al derecho interno.

El derecho interno de un Estado, a partir de la Constitución, y por decisión del constituyente, no podría ser entendido de otra manera, $y$ así en la Carta de 1925, como en la Constitución de 1980, se exige la asimilación del mejor modo posible a la necesidad de congruencia entre la Constitución y el Derecho Internacional cuando entre ellos no existe contradicción. La interpretación jurídica hecha por el juez en jurisdicción interna debe esmerarse por "cerrar" el sistema "en armonía con la fuente internacional, de modo tal que en cada caso y en cada circunstancia aquella interpretación, auxiliada por la integración coherente de los vacíos normativos, rinda el beneficio más valioso para la persona humana» ${ }^{21}$.

El texto de un tratado sobre derecho humanitario internacional o sobre derechos humanos forma parte de un contexto, "en el que su sentido integral se esclarece con el objeto y el fin del tratadon, principio hermenéutico que ha sido consagrado en el artículo 31.1 de la Convención de Viena sobre derechos de los tratados, la cual sistematiza principios interpretativos vigentes con anterioridad a la aprobación de dicho tratado.

Las normas de derecho interno y de derecho internacional de derechos humanos sólo "reconocen" y "aseguran" derechos, no los "constituyen", no los "crean", como lo señala expresamente la Constitución de 1980 en sus artículos $5^{\circ}$, inciso $2 .^{\circ}$, y encabezamiento del artículo 19, la constancia de los derechos en las normas escritas sólo significa vigencia normológica; la vigencia sociológica radica en su cumplimiento y aplicación práctica, en su efectividad.

La interpretación de las normas referentes a derechos que conforman el orden jurídico puede presentar lagunas o vacíos y debe realizarse, por parte de los operadores jurídicos, especialmente por los jueces, mediante una apelación al conjunto de valores y principios, co-

21 BIDART CAMPOS, Germán: "La interpretación de los derechos humanos en la jurisdicción internacional y en la jurisdicción interna". Ponencia al Congreso lberoamericano de Derecho Constitucional, México, 1994, pág. 13. 
mo el contexto histórico que alimentan a dicho ordenamiento jurídico como Estado de derecho constitucional democrático, lo que permite llenar los silencios o las carencias normativas para darle plenitud al sistema de derechos.

A su vez, el operador jurídico debe siempre optar por la alternativa preferencial, por la norma y la solución que mejor satisfaga la protección de los derechos, y con ello, la dignidad de la persona humana. Este principio es aplicado por la Corte Interamericana de Derechos Humanos, OC 7/85, al establecer que si a una situación determinada le son aplicables dos normas diferentes, provenientes de distintos tratados, debe prevalecer la norma que sea más favorable a la dignidad y protección de los derechos esenciales de la persona humana. Este principio hermenéutico es perfectamente válido para ser aplicable en el caso de normas de derecho interno y de derecho internacional de derechos humanos, debiendo preferirse la que mejor proteja los derechos humanos, porque el sistema en su integralidad lo exige, sea ello una norma explícita o implícita.

De esta fuerza vinculante de los derechos esenciales de la persona se desprende la invalidez de los actos o poderes públicos que los desconozcan o sean resultado de un procedimiento en el curso del cual ellos hayan sido ignorados.

\subsection{La intangibilidad de los tratados en materia de derechos humanos}

Así, tanto la Constitución de 1980 se inserta, en materia de derecho humanitario internacional y derecho internacional de los derechos humanos, en un contexto internacional que exige al Estado de Chile cumplir sus obligaciones internacionales libremente contraídas a través de las cuales ha autolimitado su soberanía, lo que es propio de todo Estado de Derecho, donde el Estado se regula por el derecho, lo que los diferencia de los Estados autocráticos.

Así, los órganos constituidos y el poder constituyente derivado carecen constitucionalmente de competencia para modificar o derogar los tratados de derecho humanitario internacional, como los tratados de derechos humanos, en virtud del principio de intangibilidad de los tratados reconocido por el constituyente a través de la historia fidedigna del establecimiento de la Constitución. 
Abona esta tesis las expresiones del Presidente de la Comisión de Estudios de la Nueva Constitución, señor Ortúzar, quien encontrando razón al señor Guzmán respecto de la intangibilidad de los tratados internacionales, señalando que le preocupa que en el futuro se interprete la expresión "fuerza de ley" como que el sistema institucional acepta que una norma legal pueda modificar los acuerdos con otros países, porque se destruiría la firmeza de la defensa chilena respecto a su intangibilidad y serían susceptibles de revisión los límites nacionales fijados por tratados (sesión 317, página 2.587) )"22.

Los tratados internacionales son intangibles, en el plano interno, en cuanto su contenido no se oponga a la Constitución, como bien lo señala Alejandro Silva Bascuñán, en la sesión 364 de la Comisión de Estudios de la Nueva Constitución (página 2.453).

Hemos sostenido, y concuerdan con nosotros Fiamma y Mohor, que el poder normativo interno, sea en su expresión constituyente y legislativa, no pueden modificar ni derogar los tratados ${ }^{23}$.

De tal forma que la reforma de la Constitución por el poder constituyente derivado, que modificara un tratado internacional o lo derogara, sería inconstitucional, quedando expuesto, previo requerimiento, a la declaración de inconstitucionalidad de parte del Tribunal Constitucional.

Chile se encuentra vinculado por la Constitución Política de la República y por los Pactos Internacionales de Derechos Humanos ratificados por Chile y que se encuentran vigentes, teniendo el deber constitucional de respetarlos y promoverlos, no pudiendo sustraerse de tal obligación constitucional establecida en las Bases de la Institucionalidad, artículo $5 .^{\circ}$, inciso $2 .^{\circ}$, de la Constitución, sin incurrir en notable abandono de deberes, como asimismo exponer la seguridad y el honor del Estado o de Chile en el campo internacional y debilitar el Estado de Derecho y los principios del constitucionalismo democrático que constituyen el soporte ético y jurídico de la Carta Fundamental y de la Nación chilena.

22 FIAMMA, Gustavo, y MOHOR, Salvador: "La jerarquía normativa de los tratados internacionales", Diario El Mercurio, Cuerpo D, del 4 de noviembre de 1994, pág. 25.

${ }^{23}$ Fiamma, Gustavo, y Mohor, Salvado, op. cit., pág. 25. 


\section{MEDIOS INTERNACIONALES DE PROTECCIÓN DE LOS DERECHOS FUNDAMENTALES}

En el caso de que los medios jurídicos internos de reparación de los derechos humanos no existan, se hayan agotado sin tener éxito o no sean tales medios efectivos, la protección de los derechos puede hacerse a través de los mecanismos internacionales.

Hay en este ámbito una fuerte interrelación entre el derecho constitucional y el derecho internacional público.

Al iniciar estas consideraciones debemos insistir en que el sistema internacional de protección de los derechos humanos tiene un carácter subsidiario y complementario del correspondiente a los tribunales nacionales. En todo caso, cuando intervienen los organismos internacionales verifican la conformidad de todas las normas estatales, todo el derecho interno (desde la Constitución, pasando por las leyes, actos administrativos, hasta llegar a las sentencias de los tribunales internos), a fin de verificar su conformidad con las obligaciones internacionales asumidas por el Estado, especialmente en materia de Pactos Internacionales o tratados en materia de derechos humanos.

En esta perspectiva, una sentencia de cualquier tribunal nacional puede comprometer el honor y la responsabilidad internacional del Estado, sin perjuicio de vulnerar el propio ordenamiento jurídico interno, si falla un asunto ignorando el derecho internacional de los derechos humanos o realizando una interpretación violatoria de un tratado en la materia. Ello se debe a que los tribunales nacionales ya no son los intérpretes finales de las obligaciones internacionales del Estado en materia de derechos humanos, interpretación final que queda en manos de los órganos de supervisión o jurisdiccionales que crea y desarrolla el tratado o sus protocolos complementarios (Comité de Derechos Humanos de Naciones Unidas; Comisión de Derechos Humanos y Corte Interamericana de Derechos Humanos).

Para citar un solo ejemplo, la determinación de si un precepto de la Convención Americana de Derechos Humanos es de ejecución inmediata (self executing) o no, ello está determinado por el derecho internacional y su órgano de aplicación, que es la Corte Interamericana del Derechos Humanos, a través de sus opiniones consultivas y de sus sentencias; al respecto los tribunales nacionales deben seguir esa interpretación, ya que si no lo hacen comprometen gravemente la responsabilidad internacional y el honor del Estado, además de su responsabilidad interna de acuerdo con el ordenamiento jurídico del Estado respectivo. 
Así, los organismos y tribunales internacionales o supranacionales competentes constituyen los intérpretes últimos en relación a las obligaciones internacionales de los Estados en materia de derechos humanos.

\subsection{El Sistema Interamericano de Protección de los Derechos Humanos}

La Convención Americana de Derechos Humanos, o Pacto de San José de Costa Rica, establece en su artículo 33, como organismos competentes para conocer de los asuntos relacionados con el cumplimiento de los compromisos por los Estados Partes, la Comisión Interamericana de Derechos Humanos y la Corte Interamericana de Derechos Humanos (la Corte en adelante).

\section{a) La Comisión Interamericana de Derechos Humanos}

La Comisión está integrada por miembros elegidos a título personal por la Asamblea General de la Organización de Estados Americanos (OEA en adelante), de una lista de candidatos propuestos por los Estados miembros que integran la OEA, tal como lo establecen los artículos 34 al 36 de la Convención Americana de Derechos Humanos (CADH en adelante). Tales postulantes deben ser personas de alta autoridad moral y reconocida versación en materia de derechos humanos (art. 34). Ellos son elegidos por cuatro años y sólo pueden ser reelegidos una vez. No puede formar parte de la Comisión más de un nacional de cada Estado Parte (art. 37).

La función principal de la comisión es la de promover la observancia y la defensa de los derechos humanos; teniendo las funciones y atribuciones que precisa el artículo 41 de la $C A D H$, ellas son las siguientes:

a) Estimular la conciencia de los derechos humanos en los pueblos de América.

b) Formular recomendaciones, cuando lo estime conveniente, a los gobiernos de los Estados miembros para que adopten medidas progresivas en favor de los derechos humanos dentro del marco de sus leyes internas y sus preceptos constitucionales, al igual que disposiciones apropiadas para fomentar el debido respeto a esos derechos. 
c) Preparar los estudios e informes que considere convenientes para el desempeño de sus funciones.

d) Solicitar de los gobiernos de los Estados miembros que le proporcionen informes sobre las medidas que adopten en materia de derechos humanos.

e) Atender las consultas que, por medio de la Secretaria General de la Organización de los Estados Americanos, le formulen los Estados miembros en cuestiones relacionadas con los derechos humanos $y$, dentro de sus posibilidades, les prestará el asesoramiento que éstos le soliciten.

f) Actuar respecto de las peticiones y otras comunicaciones en ejercicio de su autoridad en conformidad con lo dispuesto en los artículos 44 a 51 de esta Convención, y

g) Rendir un informe anual a la Asamblea General de la Organización de los Estados Americanos.

El artículo 42 de la CADH dispone que:

"Los Estados partes deben remitir a la Comisión copia de los informes $y$ estudios que en sus respectivos campos someten anualmente a las Comisiones Ejecutivas del Consejo Interamericano Económico y Social y del Consejo Interamericano para la Educación, la Ciencia y la Cultura, a fin de que aquélla vele por que se promuevan los derechos derivados de las normas económicas, sociales y sobre educación, ciencia y cultura, contenidas en la Carta de la Organización de los Estados Americanos, reformada por el Protocolo de Buenos Aires." Asimismo, el artículo 43 señala que:

"Los Estados Partes se obligan a proporcionar a la Comisión las informaciones que ésta les solicite sobre la manera en que ese derecho interno asegura la aplicación efectiva de cualesquiera disposiciones de esta Convención."

En lo referente a quienes pueden presentar a la Comisión peticiones que contengan denuncias o quejas de violación de la Convención por un Estado Parte, los artículos 44 y 45 de la CADH nos señalan que pueden ser:
a) Cualquier persona o grupo de personas.
b) Una entidad no gubernamental legalmente reconocida en uno o más Estados miembros de la organización.


c) Los Estados Parte que hayan reconocido la competencia de la Comisión para recibir y examinar las comunicaciones en que un Estado Parte alegue que otro Estado parte ha incurrido en violaciones de los derechos humanos establecidos en la convención.

Para que una petición o comunicación presentada por las personas, entidades gubernamentales o Estado Parte, que son los sujetos legitimados, sea admitida por la Comisión, debe cumplir los siguientes requisitos establecidos por el artículo 46 de la CADH:

11. a) que se hayan interpuesto y agotado los recursos de jurisdicción interna, conforme a los principios del Derecho Internacional generalmente reconocidos;

b) que sea presentada dentro del plazo de seis meses, a partir de la fecha en que el presunto lesionado en sus derechos haya sido notificado de la decisión definitiva;

c) que la materia de la petición o comunicación no esté pendiente de otro procedimiento de arreglo internacional, y

d) que en el caso del artículo 44 la petición contenga el nombre, la nacionalidad, la profesión, el domicilio y la firma de la persona o personas o del representante legal de la entidad que somete la petición.

2. Las disposiciones de los incisos 1.a) y 1.b) del presente artículo no se aplicarán cuando:

a) no exista en la legislación interna del Estado de que se trata el debido proceso legal para la protección del derecho o derechos que se alega han sido violados;

b) no se haya permitido al presunto lesionado en sus derechos el acceso a los recursos de la jurisdicción interna, o haya sido impedido de agotarlos, $y$

c) haya retardo injustificado en la decisión sobre los mencionados recursos."

Las causales de inadmisibilidad de las peticiones o comunicaciones hechas a la comisión, se producen cuando:

a) Faltan algunos de los requisitos de admisibilidad antes señalados y establecidos en el artículo $46 \mathrm{CADH}$;

b) No exponga hechos que caractericen una violación de derechos garantizados por la convención; 
c) Cuando resulte de la exposición del peticionario o del Estado manifiestamente infundada la petición o comunicación o sea evidente su total improcedencia, $y$

d) Sea sustancialmente la reproducción de una petición o comunicación anterior ya examinada por la comisión $u$ otro organismo internacional.

Una vez admitida a tramitación la petición o comunicación, se sigue un procedimiento regulado por el artículo 48 de la CADH, en los siguientes términos:

a) Se solicitará informaciones al Gobierno del Estado al cual pertenezca la autoridad señalada como responsable de la violación alegada, transcribiendo las partes pertinentes de la petición o comunicación. Dichas informaciones deben ser enviadas dentro de un plazo razonable, fijado por la Comisión al considerar las circunstancias de cada caso.

b) Recibidas las informaciones o transcurrido el plazo fijado sin que sean recibidas, verificará si existen o subsisten los motivos de la petición o comunicación. De no existir o subsistir, mandará archivar el expediente.

c) Podrá también declarar la inadmisibilidad o la improcedencia de la petición o comunicación, sobre la base de una información o prueba sobrevinientes.

d) Si el expediente no se ha archivado y con el fin de comprobar los hechos, la Comisión realizará, con conocimiento de las partes, un examen del asunto planteado en la petición o comunicación. Si fuere necesario y conveniente, la Comisión realizará una investigación para cuyo eficaz cumplimiento solicitará, y los Estados interesados le proporcionarán todas las facilidades necesarias.

e) Podrá pedir a los Estados interesados cualquier información pertinente $y$ recibirá, si así se le solicita, las exposiciones verbales o escritas que presenten los interesados.

f) Se pondrá a disposición de las partes interesadas, a fin de llegar a una solución amistosa del asunto fundada en el respeto a los derechos humanos reconocidos en esta Convención. 
En el caso de situaciones graves y urgentes, puede realizarse una investigación previo consentimiento del Estado en cuyo territorio se alegue haberse cometido la violación, tan sólo con la presentación de una petición o comunicación que reúna los requisitos formales de admisibilidad.

En la situación de que se haya llegado a una amistosa solución con arreglo a las disposiciones del inciso 1.f) del artículo 48, la Comisión redactará un informe que será transmitido al peticionario y a los Estados Partes en esta Convención y comunicado después, para su publicación, al Secretario General de la Organización de los Estados Americanos. Este informe contendrá una breve exposición de los hechos y de la solución lograda. Si cualquiera de las partes en el caso lo solicitan, se les suministrará la más amplia información posible.

Si no se llega a una solución, dentro del plazo que fije el Estatuto de la Comisión, ésta redactará un informe en el que expondrá los hechos $y$ sus conclusiones. Si el informe no representa, en todo o en parte, la opinión unánime de los miembros de la Comisión, cualquiera de ellos podrá agregar a dicho informe su opinión por separado. También se agregarán al informe las exposiciones verbales o escritas que hayan hecho los interesados en virtud del inciso 1.e) del artículo 48.

El informe será transmitido a los Estados interesados, quienes no estarán facultados para publicarlo.

Al transmitir el informe, la Comisión puede formular las proposiciones y recomendaciones que juzgue adecuadas.

Si en el plazo de tres meses, a partir de la remisión a los Estados interesados del informe de la Comisión, el asunto no ha sido solucionado o sometido a la decisión de la Corte por la Comisión o por el Estado interesado, aceptando su competencia, la Comisión podrá emitir, por mayoría absoluta de votos de sus miembros, su opinión y conclusiones sobre la cuestión sometida a su consideración. En ella la Comisión hará las recomendaciones pertinentes y fijará un plazo dentro del cual el Estado debe tomar las medidas que le competen para remediar la situación examinada.

Transcurrido el período fijado, la Comisión decidirá, por la mayoría absoluta de votos de sus miembros, si el Estado ha tomado o no medidas adecuadas y si publica o no su informe. 


\section{b) La Corte Interamericana de Derechos Humanos}

Integración y funcionamiento

La Corte se integra por siete jueces, nacionales de los Estados miembros de la Organización, elegidos a título personal entre juristas de la más alta autoridad moral, de reconocida competencia en materia de derechos humanos, que reúnan las condiciones requeridas para el ejercicio de las más elevadas funciones judiciales conforme a la ley del país del cual sean nacionales o del Estado que los proponga como candidatos. En ningún caso puede haber dos jueces de la misma nacionalidad, según determina el artículo 52.

Los jueces de la Corte son elegidos por un periodo de seis años y sólo pueden ser reelegidos una vez, según dispone el artículo $54 \mathrm{de}$ la $\mathrm{CADH}$.

El quórum para las deliberaciones de la Corte es de cinco jueces. La Comisión comparecerá en todos los casos ante la Corte.

\section{Competencia y funciones}

La legitimación activa para someter casos a la Corte corresponde únicamente a la Comisión y a los Estados Parte, tal como señala el artículo 61. A su vez, para que la Corte pueda conocer de cualquier caso, es necesario que se hayan agotado los procedimientos previstos en los artículos 48 a 50 ante la Comisión, que ya han sido descritos con anterioridad.

La función jurisdiccional de la Corte

El artículo 62 de la CADH establece el sistema de reconocimiento por parte de los Estados Partes de la jurisdicción y competencia de la Corte. Tal disposición señala al respecto:

«1. Todo Estado Parte puede, en el momento del depósito de su instrumento de ratificación o adhesión de esta Convención, o en cualquier momento posterior, declarar que reconoce como obligatoria de pleno derecho y sin convención especial, la competencia de la Corte sobre todos los casos relativos a la interpretación o aplicación de esta Convención. 
2. La declaración puede ser hecha incondicionalmente, o bajo condición de reciprocidad, por un plazo determinado o para casos específicos. Deberá ser presentada al Secretario General de la Organización, quien transmitirá copias de la misma a los otros Estados miembros de la Organización y al Secretario de la Corte.

3. La Corte tiene competencia para conocer de cualquier caso relativo a la interpretación y aplicación de las disposiciones de esta Convención que le sea sometido, siempre que los Estados Partes en el caso hayan reconocido o reconozcan dicha competencia, ora por declaración especial, como se indica en los incisos anteriores, ora por convención especial.»

La Corte, una vez que entra a conocer de una materia específica, puede adoptar diferentes medidas, las que están explicitadas en el artículo 63 de la $\mathrm{CADH}$, de la siguiente forma:

"1. Cuando decida que hubo violación de un derecho o libertad protegidos en esta Convención, la Corte dispondrá que se garantice al lesionado en el goce de su derecho o libertad conculcados. Dispondrá asimismo, si ello fuera procedente, que se reparen las consecuencias de la medida o situación que ha configurado la vulneración de esos derechos y el pago de una justa indemnización a la parte lesionada.

2. En casos de extrema gravedad y urgencia, y cuando se haga necesario evitar daños irreparables a las personas, la Corte, en los asuntos que esté conociendo, podrá tomar las medidas provisionales que considere pertinentes. Si se tratare de asuntos que aún no estén sometidos a su conocimiento, podrá actuar a solicitud de la Comisión.»

El fallo de la Corte será siempre motivado, en caso de no existir una opinión unánime de los jueces, cualquiera de ellos tendrá derecho a que se agregue al fallo su opinión disidente o individual, según dispone el artículo 66 de la CADH.

La sentencia o fallo de la Corte es definitivo e inapelable. En caso de desacuerdo sobre el sentido o alcance del fallo, la Corte lo interpretará a solicitud de cualquiera de las partes, siempre que dicha solicitud se presente dentro de los noventa días a partir de la fecha de la notificación del fallo.

La parte del fallo que establezca una indemnización compensatoria se podrá ejecutar en el respectivo país por el procedimiento interno vigente para la ejecución de sentencias contra el Estado, según dispone el artículo 68.2. 
Finalmente, el fallo de la Corte será notificado a la partes en el caso y transmitido a los Estados Partes de la Convención (art. 69).

Otras competencias de la Corte

Además de la función jurisdiccional analizada, la Corte tiene una función consultiva, que se encuentra regulada en el artículo 64 de la $\mathrm{CADH}$, la que señala en sus dos párrafos lo siguiente:

“1. Los Estados miembros de la Organización podrán consultar a la Corte acerca de la interpretación de esta Convención o de otros tratados concernientes a la protección de los derechos humanos en los Estados Americanos. Asimismo, podrán consultarla, en lo que les compete, los órganos enumerados en el Capítulo $X$ de la Carta de la Organización de los Estados Americanos, reformada por el Protocolo de Buenos Aires.

2. La Corte, a solicitud de un Estado miembro de la Organización, podrá darle opiniones acerca de la compatibilidad entre cualquiera de sus leyes internas y los mencionados instrumentos internacionales."

Finalmente, como dispone el artículo 65 de la CADH, "la Corte someterá a consideración de la Asamblea General de la Organización en cada periodo ordinario de sesiones un informe sobre su labor en el año anterior. De manera especial y con las recomendaciones pertinentes, señalará los casos en que un Estado no haya dado cumplimiento a sus fallos.»

\section{LA JURISPRUDENCIA CHILENA DE LOS TRIBUNALES DE} JUSTICIA EN MATERIA DE LA RELACIÓN ENTRE DERECHO INTERNO Y DERECHO INTERNACIONAL BAJO LA CONSTITUCIÓN DE 1925

Bajo la Carta de 1925, el artículo 43, n. ${ }^{\circ} 5$, establecía la atribución exclusiva del Congreso de aprobar o desechar los tratados que le presentare el Presidente de la República antes de su ratificación, los cuales tendrían en el Congreso los mismos trámites de una ley. 
El Presidente de la República, a su vez, firmaba y ratificaba los tratados; la ratificación podrá hacerla sólo después de la aprobación del Congreso.

\subsection{La primacía del derecho internacional consuetudinario}

La Corte Suprema chilena ha reconocido la primacía del derecho internacional consuetudinario sobre el derecho interno chileno en caso de conflicto, en 1955, en la causa LAURITZEN contra FISCO. En efecto, en dicho caso la Corte sostuvo en el considerando 49 "que aun en el supuesto de que pudieren tener aplicación las leyes internas, los principios del Derecho Internacional tienen prevalencia en estos casos»; a su vez, en la sección XI del fallo, que trata de la indemnización, la Corte Suprema afirmó: «Este fallo tiene la importancia de reconocer que las normas del Derecho Internacional son de aplicación preferente a las leyes locales»; finalmente, el fallo, en el número 159, expresó "que no es el caso tampoco, como sostiene la defensa del Fisco, pensar que pueden cobrar función jurídica los principios de la mora que establece nuestro Derecho Civil, porque se ha demostrado, en este caso, que los principios del Derecho Internacional prevalecen sobre el Derecho Interno".

La misma Corte Suprema, en 1959, en un caso de extradición activa, consideró: "Que por lo tanto, y de acuerdo con el citado artículo 637 del Código de Procedimiento Penal, es forzoso recurrir a los principios del Derecho Internacional para obtener un pronunciamiento acerca de la extradición de que se trata, principios que, por otra parte, priman siempre sobre los preceptos del Derecho Interno del Estado" ${ }^{24}$.

La Corte Suprema reafirmó la primaria del derecho internacional sobre el derecho interno chileno en un caso en 1969, dejando sin efecto una sentencia de un juzgado del trabajo, en contra de la República de China, por salarios y beneficios de un empleado chileno, reconociendo el principio de derecho internacional, universalmente reconocido, que ni las Naciones Soberanas ni sus Gobernantes están sometidos a la jurisdicción de los tribunales de otros países ${ }^{25}$. El mismo principio mantuvo en sus fallos de 1975 en un juicio contra el embajador de Cuba, para declarar nula la compraventa en 1972 de una propiedad que

\footnotetext{
${ }_{25}$ Caso Embajada de la República de China, Revista Fallos del Mes, septiembre de 1969, págs. 223-224.
} pág. 66.

${ }^{24}$ Revista de Derecho y Jurisprudencia, tomo LVI, 2. ${ }^{a}$ parte, Sección 4. ${ }^{\text {, }}$ 
servía como local de la misión cubana, sosteniendo que el juez carecía de jurisdicción para conocer de esa demanda y para pronunciar la sentencia, aplicándole al juez titular que conoció de la materia la medida disciplinaria de dos meses de suspensión de sus funciones ${ }^{26}$.

A su vez, la Corte Suprema, en un caso sobre el ejercicio de las profesiones liberales, expresó que "es inaceptable en Derecho que un Tratado Internacional puede ser modificado por acto unilateral de uno de los contratantes" ${ }^{27}$.

Estas sentencias muestran que la Corte Suprema ha determinado en variadas oportunidades acerca de la supremacia de los principios del derecho internacional y las normas de derecho consuetudinario como formando parte, en cuanto ius gentium, del ordenamiento jurídico chileno con primacía sobre las leyes internas.

El último caso señalado nos muestra que también el derecho convencional internacional prevalece sobre el derecho interno en caso de conflicto, de otra manera se violaría el derecho internacional y se comprometería el honor del Estado chileno.

\subsection{El período autoritario bajo la Constitución de $\mathbf{1 9 8 0}$ (11 de marzo de 1980 - 11 de marzo de 1990)}

Durante este lapso de nueve años, la jurisprudencia de los tribunales superiores de justicia en materia de aplicación del derecho constitucional internacional que contienen normas de derechos humanos, sin que ello implique que se trata de Tratados específicos de derechos humanos, se expresó en forma heterogénea.

En efecto, algunas sentencias aplican preferentemente el tratado sobre la ley ${ }^{28}$ :

${ }^{26}$ Caso Presidente del Consejo de Defensa del Estado, Revista Fallos del Mes, junio de 1975, pág. 90.

27 Fallo de la Corte Suprema en el caso de un costarricense, que invocaba los beneficios concedidos por la convención sobre ejercicios de las profesiones liberales, firmado en México en 1902.

28 Fernández Saldas, Luz María y Marcela: "La Protección de los Derechos Humanos en Chile. La Reforma al Artículo V de la Constitución». Memoria para optar al grado de licenciado en Ciencias Jurídicas, Universidad de Valparaíso, Chile, 1993. 
Así la Corte Suprema, en fallo de 28 de diciembre de 1983, acoge un recurso de queja recaído sobre sentencia de la Corte de Apelaciones, estableciendo en su considerando tercero, lo siguiente: "Que es un hecho no discutido en dicho proceso, que el recargo del $100 \%$ de los tributos con que se gravó la patente anual del automóvil reclamante, resultó indebidamente aplicado, toda vez que dicho gravamen respecto de determinados vehículos motorizados no podía ser exigible, por cuanto contravenía lo dispuesto en el acuerdo general sobre aranceles aduaneros y comercio GATT, vigente desde marzo de 1949, Tratado Internacional que una vez suscrito por Chile no puede sufrir derogaciones, modificaciones o suspensiones por medio de disposiciones contenidas en preceptos legales de orden interno".

A su vez, la Corte de Apelaciones de Santiago, en sentencia de 7 de marzo de 1988, concluye en la superior jerarquía del tratado sobre la ley interna, sosteniendo en su considerando cuarto: "Por otra parte, siendo un tratado un acto bilateral, es inaceptable que pueda ser modificado por una ley interna dictada en uno de los países contratantes, acto unilateral de una sola de las partes que, en consecuencia, no puede aplicarse a las importaciones de productos desde los paises que suscribieron el citado acuerdo GATT" (Revista de Derecho y Jurisprudencia, tomo LXXXV, 2.a parte, sección 2.”, pág. 12).

A su vez, tanto la Corte Suprema como el Tribunal Constitucional hasta 1988, han sostenido la primacía de la Constitución sobre las decisiones de los Tratados Internacionales.

En efecto, el Tribunal Constitucional, en sentencia de 1987, en el caso Almeyda, estableció en su fundamento 28: "Que la prevalencia en el orden interno, de los preceptos constitucionales sobre las disposiciones de un tratado, resulta, por lo demás, del todo consecuente con el sistema jurídico, ya que la interpretación contraria significa permitir la reforma de la Carta Fundamental por un modo distinto del establecido en sus artículos 116 a 118 . De allí que dicha prevalencia, tanto en la doctrina nacional como extranjera, sea la generalmente aceptada, salvo en aquellos casos excepcionalísimos en que la propia preceptiva constitucional respectiva establezca lo contrario».

Finalmente, la Corte Suprema, en sentencia del 14 de noviembre de 1988, en su considerando 13, señaló: "Que tratándose de garantías constitucionales, cuyo ejercicio está expresamente amparado con un recurso establecido en la propia Constitución, forzoso es concluir que corresponde entender que las normas de ésta última prevalecen en función de lo que disponga una Convención de carácter internacional 
que jurídicamente tiene valor la ley, y que, por lo tanto, conforme a nuestra jerarquía legal no puede disponer más allá de la Constitución que se reconoce universalmente como a la "Suprema Ley" (Revista de Derecho y Jurisprudencia, tomo LXXXV, $n .^{\circ} 3$, septiembre-diciembre 1988, 2.. parte, sección 5. ’ pág. 259).

\subsection{La jurisprudencia de los tribunales emanada después de la reforma del artículo $5 .^{\circ}$, inciso $2 .^{\circ}$, de la Constitución de 1989}

Esta jurisprudencia se agrupa en seis materias diferentes.

Claudio Troncoso, en un trabajo inédito consultado, expone algunas de estas sentencias, agrupadas en dos materias que son: Libertad Provisional y Ley de Cheques en relación con la prisión por deudas y el tema de la imprescriptibilidad de los Derechos Humanos ${ }^{29}$, que aplican los principios analizados anteriormente.

El autor mencionado cita en su trabajo las siguientes sentencias:

\section{a) Libertad provisional y Ley de Cheques}

Sentencia de la Corte Suprema de 2 de mayo de 1991, que confirma una sentencia de la Corte de Apelaciones de Santiago que le otorga al procesado la liberad provisional en causa por giro doloso de cheques fijándole una fianza de $\$ 500.000$, no cumpliendo los requisitos establecidos por el artículo 44 de la ley antes citada. La Corte estimó que de otra manera se trataría de una prisión por deudas. La Corte Señaló:

"Lo resuelto se encuentra además en concordancia con el artículo $7, n .^{\circ} 7$, de la Convención Americana de Derechos Humanos denominado "Pacto de San José de Costa Rica", aprobado por el Congreso Nacional y publicado en el Diario Oficial de 5 de enero de 1992, que tiene plena vigencia en nuestro pais en virtud del artículo $5 .^{\circ}$ de la Constitución Política, que establece que nadie será detenido por deudas y no cabe duda de que si aceptara la interpretación

${ }^{29}$ Troncoso, Claudio: La incorporación del Derecho Internacional de los Derechos Humanos al Derecho Chileno. Trabajo inédito, no publicado en Chile. 
del recurrente la permanencia en el recinto carcelario (del procesado) habría sido una prisión por deudas, expresamente prohibida en la actualidad. $n^{30}$

Sin embargo, en fallo de 25 de junio de 1991 la Corte Suprema cambia de posición, señalando lo siguiente:

"En el numerando 7 el comentado artículo $7 .^{\circ}$ del "Pacto de San José" asegura el derecho de que nadie será detenido por deudas, pero tal norma no resulta contrariada por el artículo 44 de la ley de cheques, en cuanto la caución que establece, desde que dada su naturaleza jurídica no se trata propiamente de la exigencia de una deuda civil sino de una simple condición legal, para que los individuos privados de la libertad por los delitos descritos en esta ley puedan obtener su excarcelación, asegurando de ese modo su comparecencia al juicio. $\|^{31}$

b) Sentencia del Juez de Castro: imprescriptibilidad de los derechos humanos

Resolución del Juez de Castro de 2 de febrero de 1992, por la cual se somete a proceso a un individuo por la responsabilidad que pudiere caberle en los hechos en que resultó muerto Héctor Arturo Hidebrando Santana Gómez, quien fue detenido por efectivos de la tenencia de Quellón, el 16 de septiembre de 1973.

La resolución señala:

"Que es público y notorio que en esa fecha acontecieron actos de muerte similar a los descritos en el fundamento anterior, a raíz de una inflexión institucional, en que las Fuerzas Armadas y de Orden tomaron el control del país, pero que en caso alguno, aun en Estado de Emergencia ameritaban lesionar los derechos fundamentales de los ciudadanos. El derechos a la vida, el derecho a un debido proceso tienen el reconocimiento del derecho internacional de los derechos humanos y en consecuencia, por ninguna razón pueden verse afectados por la acción estatal. Estos derechos, como otros de igual naturaleza, son declarados inderogables, puesto que dimanan

30 Fallos del Mes, n. ${ }^{\circ}$ 390, mayo de 1991, pág. 132.

31 Fallos del Mes, n. ${ }^{\circ}$ 391, junio de 1991, pág. 244. Sentencia repetida el 10 de septiembre de 1991. 
de la persona, que tiene atribuciones superiores al Estado, el cual debe estar permanentemente al servicio de su defensa. Así, por emanar de la esencia misma del ser humano, tienen la característica, entre otras, de ser imprescriptibles. No caducan ni se pierden por el transcurso del tiempo, ni por el hecho de no poder ejercerse, de manera que ni el decreto de amnistía 2,191, ni el transcurso del plazo, afectan su plena vigencia. ${ }^{32}$

Esta sentencia fue apelada a la Corte de Apelaciones de Puerto Montt, la que la confirmó.

Más recientemente ha habido otras seis materias que han sido objeto de sentencia de los tribunales superiores en que se han aplicado directamente los tratados ratificados por Chile y vigentes en materia de derechos humanos:

\section{a) Discriminación racial}

La Cuarta Sala de la Corte de Apelaciones de Santiago, en abril de 1993, resolviendo un recurso de apelación del "Centro de Salud y Recreación Gunter Mund y Cía. Ltda." respecto de una multa aplicada por un Juez local en fallo de primera instancia al haberse impedido el ingreso al local de una dama de nacionalidad coreana, señala:

"El hecho de impedir a una persona o grupo de personas poder entrar a un lugar público, sea gratuito o pagado, basado en circunstancias de raza, sexo, idioma, religión o cualquier otra circunstancia étnica, social o cultural implican un trato desigual y discriminatorio que contraviene los principios que hoy imperan en las sociedades modernas relativa a derechos humanos, contenidos en la Carta de Naciones Unidas, Pacto Internacional de Derechos Civiles y Políticos, Convención Americana de Derecho Humanos, que son leyes de la República en conformidad a lo dispuesto en el artículo 5. ${ }^{\circ}$, inciso 2. ', de nuestra Carta Fundamental.»

Tal acción sostiene el Tribunal, basada en el hecho de que "las costumbres alimentarias de personas de esa nacionalidad hace que tengan mal olor o que grupos de personas de esa nacionalidad hayan perturbado con sus hábitos a la clientela de ese negocio, no es menos cierto que, además de significar la conducta de los responsables del Centro de Salud Gunter Mund una discriminación racial, resulta además injusta y atentatoria a la dignidad humana». 
b) Derecho a la vida

En sentencia Rol n. ${ }^{\circ} 1561-92$, una Sala de la Corte de Apelaciones de Santiago, con fecha 2 de julio de 1992, determinó en un recurso de protección interpuesto por el Intendente de la Región Metropolitana en favor de personas que se encontraban en huelga de hambre, lo siguiente:

1. Que el artículo $5 .^{\circ}$ de la Constitución en su inciso segundo establece que es deber de los órganos del Estado respetar y promover los derechos esenciales que emanan de la naturaleza humana garantizados por la Constitución, entre los cuales se encuentra fundamentalmente el derecho a la vida y a la integridad física y psíquica de las personas.

2. Que es un hecho establecido en estos antecedentes que las personas referidas en la presentación se encuentran en un estado de grave peligro para su vida, por cuanto voluntariamente se han negado a ingerir alimentos en forma sistemática desde el día 5 del mes pasado en el lugar señalado en lo expositivo de este fallo.

3. Que en esta contingencia de este fallo, haciendo uso esta Corte de sus facultades conservadoras, resuelve lo siguiente:

a) Se instruye al Director del Servicio de Salud Metropolitano Central para que disponga el traslado inmediato de las personas mencionadas en el recurso a un establecimiento asistencial médico a fin de que se les suministre la atención médica necesaria para su recuperación.

b) Que para el evento de producirse oposición se decreta ya el auxilio y fuerza pública para el cumplimiento de lo decretado.

c) Respeto a la vida privada y honra de las personas en relación con la libertad de expresión e información

En causa Rol $n .^{\circ}$ 983-93, de recurso de protección, la Corte de Apelaciones de Santiago, en fallo de fecha 31 de mayo de 1993, luego confirmado por la Corte Suprema por fallo del 15 de junio de 1993, aplicando directamente los Pactos Internacionales en materia de derechos humanos, señaló: 
«9. ${ }^{\circ}$ Que lo concluido en los considerandos anteriores es plenamente coherente con lo dispuesto en los tratados internacionales sobre derechos esenciales que emanen de la naturaleza humana, ratificados por Chile y vigentes en nuestro país, siendo suficiente para esta magistratura citar al efecto los artículos 17 y 19, números 2 y 3, del Pacto Internacional de Derechos Civiles y Políticos, los cuales al tratar estos derechos confieren manifiestamente mayor jerarquía a la privacidad y a la honra que a la libertad de expresión e información. Desde luego, permite la restricción previa, siempre que esté expresamente fijada en la ley y sea necesaria para asegurar el respeto a los derechos o a la reputación de los demás y también la moral pública, lo que es plenamente aplicable al caso de autos.

Todavía más, el artículo $4 .^{\circ}$ de este Pacto permite en circunstancias excepcionales, que el mismo contempla, suspender o restringir el derecho a la libertad de expresión o información, pero no ocurre lo mismo con la privacidad y la honra, las que deben ser respetadas en toda situación.

También cabe mencionar los artículos 11 y 13 de la Convención Americana de Derechos Humanos de San José de Costa Rica, que aun cuando contempla el derecho a la libertad de expresión en forma amplisima, pues no permite ninguna forma de censura previa, ésta debe interpretarse en los términos señalados en el considerando $7 .^{\circ}$, teniendo presente que en la especie no se trata de medidas restrictivas dispuesta por el Poder Ejecutivo, que podrían calificarse de políticas, sino de medidas judiciales contempladas en la ley y que corresponden al rol tutelar que es inherente a los Tribunales de Justicia.»

\section{d) Libertad provisional de menores}

Sobre la libertad provisional de menores hay una cantidad importante de sentencias de Cortes de Apelaciones que se fundamentarán en la Convención de Derechos del Niño:

"Que tratándose de una menor de edad que delinquió a los 17 años, mayor motivo tienen aún los jueces para inclinarse en favor de la excarcelación, sobre todo si se considera que de conformidad con el artículo 37, letra b), de la Convención sobre Derechos del Niño - publicada en el Diario Oficial del 27 de septiembre de 1990-, la prisión de un niño $-y$ se entiende por tal al menor de 18 años de edad (artículo $1 .^{\circ}$ ) - se utilizará tan sólo como medida de último recurso y durante el periodo más breve que proceda. Disposición que forma parte de nuestro ordenamiento jurídico de acuerdo con el artículo $54^{\circ}$, inciso segundo, de la Constitución Política de la Repúbli- 
ca, que ordena respetar y promover los derechos establecidos por los tratados internacionales ratificados por Chile y que se encuentran vigentes." (Sentencia Rol n. $19558-a-94$. Corte de Apelaciones de Santiago)

Así, hoy es indiscutible que los tratados de derechos humanos ratificados por Chile $y$ que se encuentren vigentes son parte del derecho chileno y aplicables de inmediato si se trata de derechos civiles y políticos. Esto constituye una obligación para todos los órganos del Estado, incluidos los órganos jurisdiccionales, a los que les cabe un rol fundamental en esta materia.

e) Nulidad de confesión mediante apremio ilegítimo y vinculación de los jueces a tratados internacionales

En fallo Rol n. ${ }^{\circ} 43.488-94$, consultado a la Corte de Apelaciones una sentencia penal que condenaba a Luis Valdivia Cofré, fundada en confesión extrajudicial previo apremios ilegítimos que le provocaron lesiones por cuerpo contundente, determinados por los correspondientes informes médicos, la Corte de Apelaciones declara nula tal confesión, absolviéndolo de la acusación que se le habia formulado. A estos efectos, los considerandos en que se invocan y aplican los tratados de derechos humanos son los siguientes:

"2. Que el artículo 8.3 del Pacto de San José de Costa Rica establece que la confesión del inculpado solamente es válida si es hecha sin coacción de ninguna naturaleza.

Por su parte, el artículo 14.3, letra g), del Pacto Internacional de Derechos Civiles y Políticos, reconoce a toda persona acusada de un delito el derecho a no ser obligada a declarar contra sí misma y a confesarse culpable.

Todavía más, la Convención de las Naciones Unidas contra la Tortura y otros Tratos o Penas Crueles, Inhumanos y Degradantes define como tortura "todo acto por el cual se inflija intencionadamente a una persona dolores o sufrimientos graves, ya sean físicos o mentales, con el fin de obtener de ella o de un tercero información o una confesión... cuando dichos dolores o sufrimientos sean infligidos por un funcionario público $u$ otra persona en el ejercicio de funciones públicas..." (art. 1. ${ }^{\circ}$ ). Obliga a todo Estado parte a mantener en examen los sistemas, métodos y prácticas de interrogatorio de las personas sometidas a cualquier forma de arresto, detención o prisión, precisamente con el fin de evitar "todo caso de tortura" 
(art. 11). Y además, compele a los Estados parte a asegurarse de que ninguna declaración que se demuestre haber sido hecha como resultado de tortura "pueda ser invocada como prueba en ningún procedimiento". (art. 15).

En sus artículos $5 .^{\circ}, 7 .^{\circ}$ y 10 la Convención Interamericana para Prevenir y Sancionar la Tortura, acordada por la Organización de los Estados Americanos, repite en términos parecidos estos mismos conceptos, siendo de destacar el último de los preceptos citados que, tal como lo hace el artículo 15 que viene de reseñarse, prohíbe admitir como prueba procesal cualquier declaración "que se comprueba haber sido obtenida mediante tortura".

3. Que todas las disposiciones que vienen de recordarse son vinculantes para los jueces de la República, por cumplir plenamente las condiciones a que se refiere la frase final del inciso $2 .^{\circ} \mathrm{del}$ artículo $5 .^{\circ}$ de la Constitución Política.

Por lo demás, hoy se entienden formar parte del debido y racional procedimiento penal $y$, por tanto, también obligan a los tribunales por la vía del artículo 19 de la misma Carta Principal, en lo que hace a su numeral $3 .^{\circ}$, inciso $5^{\circ}$.

4. Que así las cosas, descartado el único elemento de cargo que la pesquisa logró reunir en contra de Luis Valdivia, no queda sino concluir que, apreciada como en este tipo de asuntos corresponde evaluarla, no logra la prueba convencer respecto de su participación criminosa en el delito por el que se le acusó, debiendo los jueces seguir en este particular la sabia regla del artículo 456 bis del Código Procesal..1 ${ }^{33}$

El fallo transcrito aplica directamente las normas del derecho internacional de los derechos hermanos y entiende que ellos se incorporan a la Constitución entendiendo, en este caso específico, que forman parte del artículo $19, n .^{\circ} 3$, inciso $5 .^{\circ}$.

También, en materia de Tratados no referentes a derechos esenciales, la Corte Suprema ha determinado la prevalencia de los tratados en el siguiente caso, confirmando jurisprudencia anteriormente citada:

«En recurso de protección interpuesto por la Compañía Chilena de Fósforos en contra de la Comisión Nacional de Distorsión de Precios, en cuanto ésta última no había dado curso en la denuncia de dumping por la incorporación de encendedores desechables provenientes de varios países asiáticos, al considerar la Comisión Nacional de Distorsión de Precios que, de acuerdo con el Tratado del Gatt 
y su interpretación, los fósforos no son "productos similares" a los encendedores desechables, ya que "producto" similar es, según el tratado del Gatt, el que tiene similitud física y no de finalidad.

Así, en fallo de la Segunda Sala de la Corte de Apelaciones de Santiago de 1994, Rol n. ${ }^{\circ}$ 3.396-94, se determinó en los considerandos respectivos, lo siguiente:

3. Que los tratados internacionales se incorporan al derecho interno de acuerdo con las normas establecidas en los artículos 32 , $\mathrm{n} .^{\circ} 17$, y $50, \mathrm{n}^{\circ} 1$, de la Constitución, y luego de su promulgación y publicación en el Diario Oficial.

4. Que una vez incorporado al derecho interno los tratados deben cumplirse de buena fe de acuerdo a la Convención de Viena sobre Derechos de los Tratados, vigente en el país desde el 27 de enero de 1980, debiendo aplicarse sus artículos 31 y 27 . El primero de ellos establece que el Tratado debe interpretarse de buena fe conforme al sentido corriente que haya de atribuirse a los términos del Tratado, en el contexto de éstos y teniendo en cuenta su objeto y fin. A su vez, el artículo 27 establece que el Estado no puede invocar la ley interna para eludir el cumplimiento del Tratado.

5. Que la convención internacional en consideración se aplica preferentemente frente a la ley interna, mientras el Tratado no sea denunciado por el Estado de Chile o pierda validez internacional."

Tal fallo fue confirmado por la Corte Suprema de Justicia por unanimidad de los cinco ministros que integraron la Primera Sala, el 11 de enero de 1995, Rol n. ${ }^{\circ}$ 24.344. Fallos publicados en Gaceta Jurídica de marzo de 1993, págs. 165-168.

Respecto a esta última materia, la Corte Permanente de Justicia Internacional ha resuelto que «es un principio del Derecho de Gentes generalmente reconocido que en las relaciones entre potencias contratantes, las disposiciones del Derecho Interno no puedan prevalecer sobre las de un Tratado" (Serie B,.$^{\circ} 17$, página 32 ). Asimismo ha sostenido que uun Estado no puede invocar frente a otro Estado su propia Constitución para sustraerse a las obligaciones que impone el Derecho Internacional a los Tratados vigentes" (Serie A/B, $n .^{\circ} 44$, página 24) ${ }^{34}$.

En tal sentido, el Juez debe intentar armonizar el mayor grado posible ambos derechos en una interpretación sistemática y finalista. Así lo estableció el Autoacordado de la Corte Suprema de Chile del 11 de abril de 1967.

34 Llanos Mansilla, Hugo: Teoría y práctica del Derecho Internacional Público, Ed. Jurídica de Chile, Santiago, Chile, 1977, pág. 485, nota 474. 
A su vez, el Juez debe examinar atentamente la intención de las Partes en el tratado, en términos de qué derechos y obligaciones se establecen y si éstos se han o no acordado para ser ejercidos por las personas. Luego debe examinarse si los derechos que otorga el Tratado son de aplicación inmediata (operativos o self-executing) o si requieren de medidas nacionales de implantación.

En materia de derechos humanos, el juez debe interpretar los tratados teniendo en cuenta su fin último, que es la protección de los derechos de las personas. Optará siempre por aquella interpretación que protege en mejor forma los derechos. Las limitaciones deben ser interpretadas en forma restrictiva, como lo dispone específicamente el artículo 29 de la Convención Americana de Derechos Humanos.

A su vez, los tribunales encargados de aplicar los derechos pueden resolver muchos problemas si tienen la voluntad efectiva de asegurar el respeto de los derechos humanos, especialmente los que les corresponde ejercer control de la constitucionalidad a petición de parte o de oficio, pueden utilizar el mecanismo de la declaración de inconstitucionalidad por omisión, determinando la existencia de una vulneración constitucional por la inactividad de algunos órganos del Estado ${ }^{35}$.

Finalmente, los jueces pueden aplicar con suficiente voluntad $y$ en cumplimiento del principio de buena fe, una interpretación que permita siempre la mayor protección de los derechos, incluso llenando las insuficiencias y vacíos, dando completitud que la norma requiere, salvaguardando así el honor y la responsabilidad del Estado frente a la comunidad internacional y realizando el fin querido por el ordenamiento constitucional, que es el de asegurar, garantizar y promover los derechos humanos (artículos $1 .^{\circ}$ y $5^{\circ}$ de la Constitución).

Ello requiere de una formación cultural de los operadores jurídicos que supere los preconceptos y resistencias a la aplicación de las normas de un orden internacional o supranacional, dándoles operatividad inmediata. El fantasma de la soberanía sigue ejerciendo su influencia aún cuando las Constituciones especifican que los derechos humanos constituyen una limitación a ella.

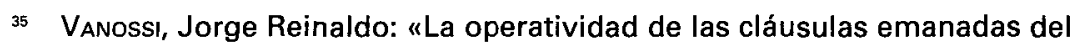
ordenamiento internacional en cuanto a su aplicabilidad en el orden interno de los Estados", Revista IIDH, n. ${ }^{\circ} 16$, julio-diciembre 1992, San José de Costa Rica. 